

\section{DISCLAIMER}

This report was prepared as an account of work sponsored by an agency of the United States Government. Neither the United States Government nor any agency Thereof, nor any of their employees, makes any warranty, express or implied, or assumes any legal liability or responsibility for the accuracy, completeness, or usefulness of any information, apparatus, product, or process disclosed, or represents that its use would not infringe privately owned rights. Reference herein to any specific commercial product, process, or service by trade name, trademark, manufacturer, or otherwise does not necessarily constitute or imply its endorsement, recommendation, or favoring by the United States Government or any agency thereof. The views and opinions of authors expressed herein do not necessarily state or reflect those of the United States Government or any agency thereof. 


\section{DISCLAIMER}

Portions of this document may be illegible in electronic image products. Images are produced from the best available original document. 


\section{The following pages are an exact representation of what is in the original document folder.}


Printed in the United States of America. Available from National Technical Information Service

U.S. Department of Commerce

5285 Port Royal Road, Springfield, Virginia 22161

NTIS price codes-Printed Copy: A04; Microfiche A01

This report was prepared as an account of work sponsored by an agency of the United States Government. Neither the United States Government nor any agency thereof, nor any of their employees, makes any warranty, express or implied, or assumes any legal liability or responsibility for the accuracy, completeness, or usefulness of any information, apparatus, product, or process disclosed, or represents that its use would not infringe privately owned rights. Reference herein to any specific commercial product, process, or service by trade name, trademark, manufacturer, or otherwise, does not necessarily constitute or imply its endorsement, recommendation, or favoring by the United States Government or any agency thereof. The views and opinions of authors expressed herein do not necessarily state or reflect those of the United States Government or any agency thereof. 
ORNL/TM- -8486

DE83 001634

\title{
Information Division
}

\section{MASTER} STATUS OF THE RESIDENTIAL CONSERVATION SERVICE PROGRAM
IN SELECTED STATES ÁS OF DECEMBER 1981

\author{
Lois M. Frogge \\ Anne R. Ehrenshaft \\ Linda E. Morris \\ Center for Energy and Environmental Information \\ Information Center Complex
}

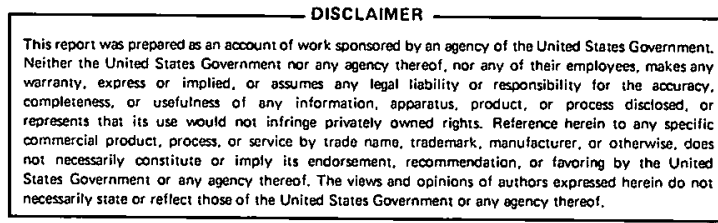

necessarily siate or reflect those of the United States Government or any agency thereol.

Date of Issue - September 1982

Prepared by the

OAK RIDGE NATIONAL LABORATORY

Oak Ridge, Tennessee 37830

operated by

UNION CARBIDE CORPORATION

for the

U.S. DEPARTMENT OF ENERGY

Under Contract No. W-7405-eng-26 


\section{五}




\section{THIS PAGE}

\section{WAS INTENTIONALLY LEFT BLANK}


CONTENTS

Tables . . . . . . . . . . . . . . . . . . . v

1. History of the Residential Conservation Service Program . . . . 1

2. Research Objective and Methodology . . . . . . . . . . 4

2.1 Research Objective . . . . . . . . . . . . . . . 4

2.2 Methodology . . . . . . . . . . . . . . . 4

2.3 Limitations of the Data . . . . . . . . . . 6

2.3.1 Ellgible Customers .............. . 7

2.3.2 Customer Response Rates . . . . . . . . . . 7

3. Program Overview of Targeted States . . . . . . . . . 13

3.1 Introduction . . . . . . . . . . . . . . . . 13

3.2 RCS and Existing Programs Overview . . . . . . . . 15

3.3 Arranging and Listing . . . . . . . . . . . . 17

3.4 Post-Installation Inspections . . . . . . . . . . . 17

3.5 Incentives . . . . . . . . . . . . . . . . 18

3.6 Sumnary . . . . . . . . . . . . . . . 18

4. State-Specific Findings . . . . . . . . . . . . . 20

4.1 Introduction . . . . . . . . . . . . . . 20

4.2 California Program Structure and Status . . . . . . . 20 4.2.1 Nonregulated Utility Programs . . . . . . . . 22

4.2.2 Unique Features .......... . . . . . 23

4.2.3 Problems and Impacts ............. . 24

4.3 Connecticut Program Structure and Status . . . . . . . . 24

4.3.1 Unique Features . . . . . . . . . . . . . . 25

4.3.2 Problems and Impacts ............. 25

4.4 Delaware Program Structure and Status . . . . . . . . 26

4.4.1 Problems and Impacts . . . . . . . . . . . 27

4.5 Iowa Program Structure and Status . . . . . . . . . 27

4.5.1 Unique Features . . . . . . . . . . . . 28

4.5.2 Problems and Impacts . . . . . . . . . . . 28

4.6 Michigan Program Structure and Status . . . . . . . . . 28

4.6.1 Problems and Impacts . . . . . . . . . . . 29

4.7 New Jersey Program Structure and Status . . . . . . . 30

4.7.1 Unique Features . . . . . . . . . . . . . 31

4.7.2 Problems and Impacts . . . . . . . . . . 31

4.8 New York Program Structure and Status . . . . . . . . 32

4.8.1 Unique Features . . . . . . . . . . . . . . 33

4.8.2 Problems and Impacts ........... . 33 
4.9 Oregon Program Structure and Status . . . . . . . . 33

4.9.1 Nonregulated Utility Programs ......... . 35

4.9.2 Problems and Impacts ............. . 35

4.10 Rhode Island Program Structure and Status . . . . . . 36

4.10.1 Unique Features . . . . . . . . . . . . 37

4.10.2 Problems and Impacts ... . . . . . . . 37

4.11 South Carolina Program Structure and Status . . . . . . 37

4.11.1 Nonregulated Utility Program . . . . . . . . 38

4.11.2 Problems and Impacts . . . . . . . . . . 38

4.12 Texas Program Structure and Status . . . . . . . . . 39

4.12.1 Problems and Impacts .. . . . . . . . . . 40

Appendix A. Interview Guide . . . . . . . . . . . . . . . . 41

Appendix B. Program Coverage . . . . . . . . . . . . . . 44 
TABLES

1. RCS Regulatory History . . . . . . . . . . . . . 2

2. RCS Program Data by State ................ 8

3. Existing Program Data by State ............... 9

4. Residential Audit Program Data by State ... . . . . . 14 


\section{HISTORY OF THE RESIDENTIAL CONSERVATION SERVICE PROGRAM}

The establishment of the Residential Conservation Service (RCS) Program was mandated by the enactment of the National Energy Conservation Policy Act (NECPA) signed into law November 9, 1978. Title II, Part I of NECPA directed the U.S. Department of Energy (DOE) to issue regulations requiring large electric and natural gas utilities to offer on-site residential energy audits and other related services to customers living in single-family dwellings or multifamily buildings with four or fewer dwelling units: Pursuant to this law, DOE issued proposed regulations on March 19, 1979, and final regulations on November 7, 1979. Because the Energy Security Act (ESA), enacted on June 30, 1980, amended provisions of existing law governing the RCS Program, DOE then issued an interpretative rule and two proposed rules to incorporate the ESA amendments into the existing RCS regulations. Proposed rules addressing previously reserved sections of the Final Rule and establishing the Commercial. and Apartment Conservation Service and the Federal RCS (Standby) Plan were also issued.

On November 12, 1981, DOE issued a revised proposed rule* greatly reducing the regulatory requirements of the previous RCS Rules imposed on States and utilities participating in the program. The ESA ammendments and the Federal RCS (Standby) Plan were withdrawn. Table 1 lists the regulations issued by DOE pertaining to RCS and related activities.

With the promulgation of the Final Rule in November 1979, a legislated timetable for RCS activities went into effect. The State lead agencies and nonregulated utilities ${ }^{\dagger}$ submitting their own plans were to develop and submit the plans to DOE within 180 days. Decisions concerning approval or disapproval were to have been made by DOE by September 1980 .

* The Final RCS Rule was published on June 25, 1982, after this report was drafted. Information in this report includes State data collected in some instances up to March 1982, but does not include information on the Final RCS Rule.

${ }^{+}$Nonregulated utilities are those utilities which do not fall under the jurisdiction of the State utility regulatory agency. In most cases, they are utilities which are operated by municipalities or rural electric cooperatives. 
Table 1. RCS Regulatory History

Date

Regulatory action and description

\begin{tabular}{|c|c|}
\hline November 9, 1978 & $\begin{array}{l}\text { National Energy Conservation Policy Act (NECPA) } \\
\text { signed }\end{array}$ \\
\hline January 9, 1979 & Advance notice of proposed rulemaking \\
\hline March 19, 1979 & Proposed rulemaking and public hearings \\
\hline November 7, 1979 & Final Rule \\
\hline June 30.1980 & Fnergy security $\Lambda \subset t$ (ESA) entahlifsheit \\
\hline August 11,1980 & $\begin{array}{l}\text { Corrections to Final Rule and interpretation of } \\
\text { TItle V, Subpart B of the Energy Security Act }\end{array}$ \\
\hline September 24,1980 & $\begin{array}{l}\text { Final Rules establishing requirements for } \\
\text { (1) certification of installers and inspectors } \\
\text { of furnace modifications and renewable resource } \\
\text { devices and ( } 2 \text { ) material and installation } \\
\text { standards which had previously been reserved. } \\
\text { Interim rule for installation standards for } \\
\text { automatic intermittent ignition devices }\end{array}$ \\
\hline September 25,1980 & $\begin{array}{l}\text { Interim Final Rule establishing materjal } \\
\text { standards for urea-formaldehyde foam insulation }\end{array}$ \\
\hline October 8,1980 & $\begin{array}{l}\text { Proposed rulemaking and public hearing to } \\
\text { incorporate statulory changes made to the KCS } \\
\text { Program by the Energy Security Act }\end{array}$ \\
\hline January 6,1981 & Final technical amendments to RCS \\
\hline January 9, 1981 & Proposed rulemaking for the Federal RCS Plan \\
\hline January 16,1981 & $\begin{array}{l}\text { Proposed rulemaking for the Commercial and } \\
\text { Apartment Conservation Service Program }\end{array}$ \\
\hline November 12,1981 & $\begin{array}{l}\text { Proposed revisions to existing rules and with- } \\
\text { diawal of the Fcderal KL's H'lail dild proposed } \\
\text { Energy Security Act amendments* }\end{array}$ \\
\hline
\end{tabular}

* The Final RCS Rule was published on June 25, 1982, after this report was drafted. 
The first program announcements were to have been distributed by the utilities by March 1981. However, this schedule was not met. Most of the RCS Plans were submitted very near the deadline, thereby creating an automatic backlog of plans for review. The review process was highly detailed; each plan was analyzed for program (policy) as well as technical (audit procedures) content. Dialogues between DOE and the program participants (State lead agencies, etc.) developed in order to bring the plans into compliance. Most plans required some revision before DOE made a final decision; therefore the schedule for program implementation became individualized on a State-by-State or utility-by-utility basis. 


\section{RESEARCH OBJECTIVE AND METHODOLOGY}

\subsection{RESEARCH OBJECTIVE}

The primary objective of this study was to collect information concerning RCS and similar residential audit programs to determine the implementation status of the RCS Programs in various parts of the country as of December 1, 1981. * To do this, about $25 \%$ of the participating States and nonregulated utilities operating independent programs in those states were contacted to ascertain (1) the number of residential customers served by the participating utilities, (2) the public response to the program (the number of requests for energy audits and arranging services), (3) the number of such requests fulfilled by the utilities, (4) the retrofit actions taken by the participants, and (5) the availability of data necessary for the determination of national costeffectiveness and energy savings.

As a consequence of delays that developed in the plan approval process and the necessity of incorporating regulatory changes in the plans, in December 1981 States and nonregulated utilities were at different stages in the process of implementing their RCS Programs. Many programs had just begun, while others had been operating for about one year. These differences were revealed as a result of the interviews conducted.

\subsection{METHODOLOGY}

The States included in this initial effort were selected without regard to the current status of their RCS Programs. Geographic and climatic differences were the important selection factors. The eleven States chosen for this project were California, Connecticut, Delaware, Iowa, Michigan, New Jersey, New York, Oregon, Rhode Island, South Carolina, and Texas. The ten nonregulated utilities within these States that were

\footnotetext{
*A partial sequel to this report, which builds on these findings and adds to them with information from interviews with corresponding national organizations and from other sources, is available at Oak Ridge National Laboratory. It is entitled Basic Considerations for the Monitoring and Evaluation of the Residential Conservation Service Progrom, ORNL/CON-98.
} 
operating RCS Programs independently from State programs were also included. They are as follows:

California - Anaheim Electric Division, Modesto Irrigation District, Los Angeles Department of Water and Power, Palo Alto Electric Utility, Riverside Public Utilities, Sacramento Municipal Utility District, and Santa Clara Electric Department

Oregon - Central Lincoln People's Utility District and Eugene Water and Electric Board

South Carolina - South Carolina Public Service Authority (Santee Cooper)

For this task, eight of the State lead agencies and all ten of the nonregulated utilities were contacted by telephone. In-person interviews were conducted with three of the lead agencies. In a few cases, utilities operating within the framework of the State programs were contacted to verify information obtained from other sources or to fill in missing information.

An interview guide was developed to elicit information in a standardized format on a wide range of RCS Program elements (Appendix A). Information was also requested on the availability of customer follow-up evaluative studies and the status of the State's utility regulatory authority ruling concerning the utility allocation of RCS costs (e.g., direct charges, rate-basing, etc.).

Prior to contacting the participants, the following were reviewed: the First Annual Program Reports to DOE, * the RCS Plans and the amendments to these plans, the list of covered utilities published in the October 1980 Federal Register, the DOE program report to Congress in August 1981 and back-up demonstration, and the Federal Trade Commission (FTC) questionnaire. ${ }^{\dagger}$ This preliminary review was an attempt to answer as many questions as possible before the interviews, thereby reducing the number of questions each contact was asked. The telephone interviews lasted from 20 to 45 minutes. The in-person interviews took approximately one hour and usually

First Annual Program Reports to DOE, July 1981 - Those entities with RCS Plans are required to report on their progress annually to DOE. The reports are due in July of each year, but some come in as late as September.

${ }^{+}$NECPA Sect. 225 requires the FTC to report to Congress before January 1, 1982, on specific RCS activities in each State concerning utility loan programs for RCS measures. 
provided more information, perhaps because the people contacted were appraised prior to the interview about the nature of information being gathered and had time to prepare for the interviews.

\subsection{LIMITATIONS OF THE DATA}

After all the program materials were reviewed and the interview phase was completed, it became apparent that there were gaps in the data obtained. The review of the State Plans revealed a lack of specifics concerning actual program responsibilities, obscure statements, and mere reiterations of the language of the RCS Rule. The Annual Program Reports lacked consistency in the reporting of program elements from state to State, omitted required information, reported estimates of intentions rather than actualities, or, if program initiation had been substantially delayed, were not submitted at all. Much of the data requested were given as estimates rather than precise numbers or were not available due to the recentness of program start-up and the lack of data acquisition activities on the part of the program participants.

Specific data gaps that frequently emerged as altogether lacking, incomplete, or inconsistently reported were:

1. information on utility supply and installation programs;

2. information on how utility arranging services were used;

3. information on types of retrofits, their average costs, and the actual or average savings resulting from the retrofits;

4. information on the exact number of eligible customers;

5. a common method of calculating customer response rates to audit offers; and

6. information on actual program cost breakdowns and budgets beyond that of salaries.

The two greatest problems resulting from the data limitations were identifying the exact number of eligible customers and calculating the customer response rates. These problems are discussed in more detail to illustrate their impact. 


\subsubsection{Eligible Customers}

The majority of utilities and States cited problems identifying eligible customers as defined by RCS* separately from residents of apartments with individual metering or from small commercial customers. Apparently due to the degree of difficulty and the expense involved in coding computerized customer records, utilities decided that all residential customers, or whatever computerized unit included residential customers, would be sent program announcements regardless of program eligibility. Many utilities group their customers according to the amount of energy used in small, medium, and large ranges. Consequently, residential owners and renters and small commercial customers may all be grouped together for billing and rate purposes, and this population, which uses similar amounts of gas or electricity, may be treated as "eligible customers." In this instance apartment residents who requested audits were informed that audits were not available. This inability to distinguish RCS eligible customers from all residential and commercial customers clearly affected the response rates quoted by the respondents and later calculated by the researchers. Therefore, response rates could be understated.

Also noted was the fact that residential customers are sometimes served by both a gas and an electric utility. Although program regulations provide that eligible customers are eligible for program services from each of the utilities which service them, in some States utilities with overlapping service areas refer audit requests to the utility company which provides the space heating. Table 2 footnotes utilities which have adjusted the number of eligible customers to reflect this agreement for overlap. (See Sect. 3.1, "Introduction to the Program, Overview of Targeted States," for further explanation of both Tables 2 and 3.)

\subsubsection{Customer Response Rates}

The response rates referred to throughout this report have been calculated on the basis of those customers receiving program announcements,

* Combining the RCS definition for eligible customers and residential buildings, eligible customers are residents of single-family dwellings or of buildings with four or fewer units who receive a fuel bill. 
Table 2. RCS Program Data by State

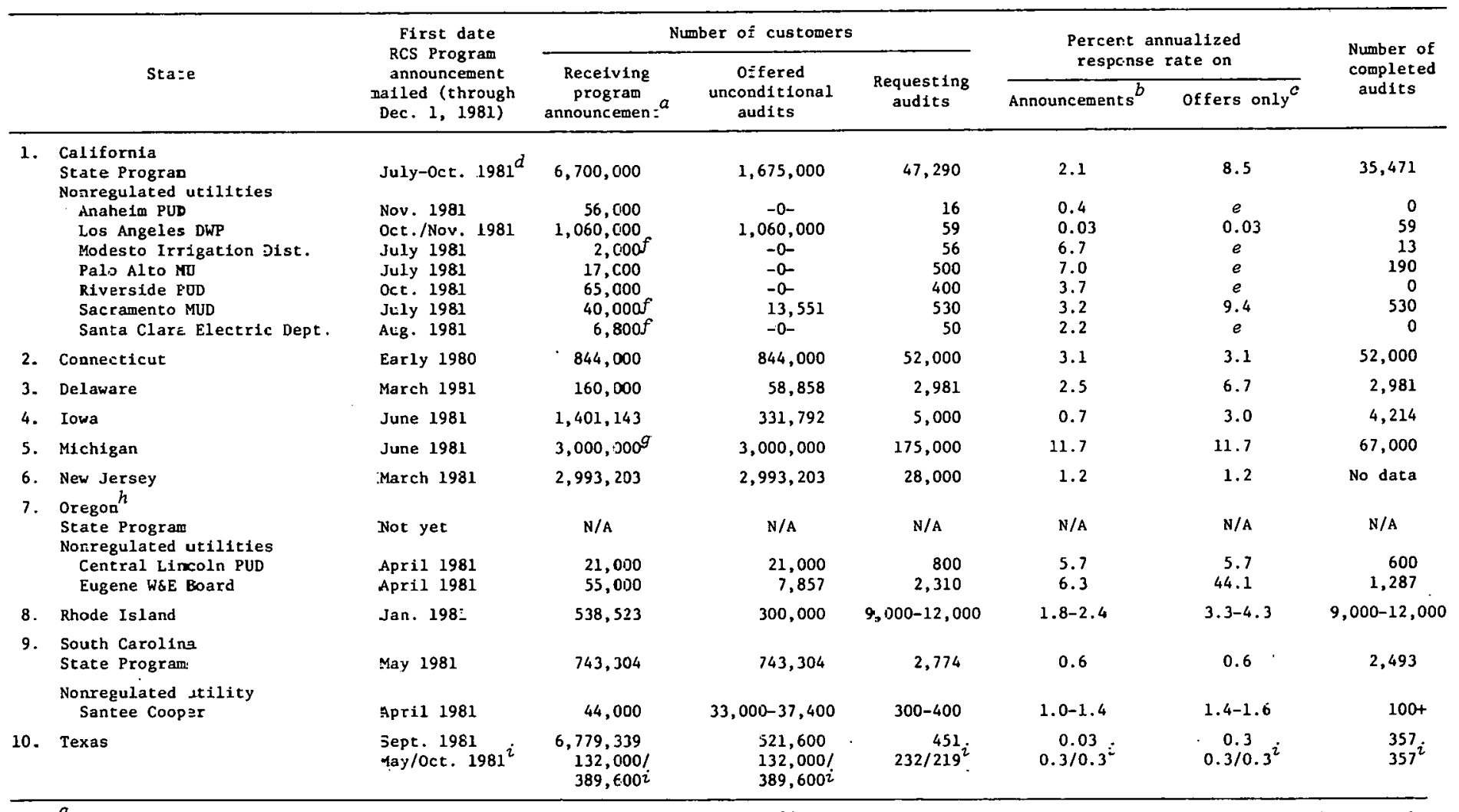

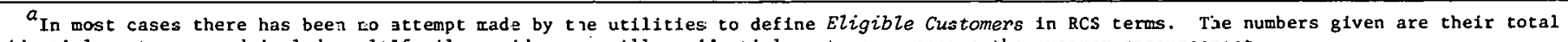
residential customers and include mLltlfamily residences. All resident1al customers rece:ve the program announcement.

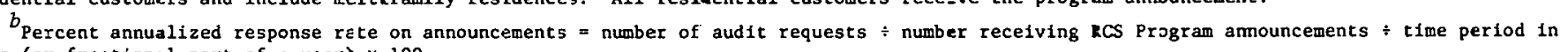
years (o: fractional part of a year) $\times 100$.

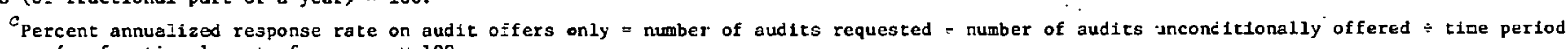
in years (or fractional part of a year: $x$ ido

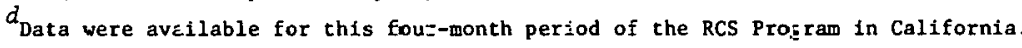

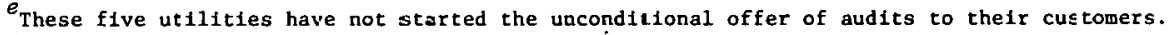

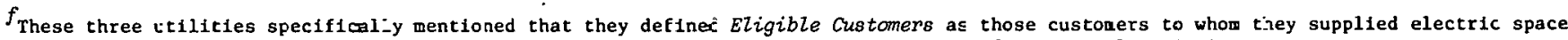
heazing (all electric homes:. Their e-ectric customers with gas heating are audited by Pacific Gas \& Electric Compazy.

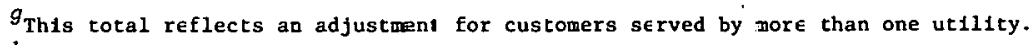

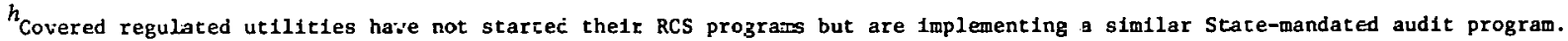

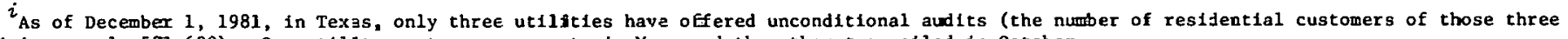
uti-ities equals 521,600$)$. One utility sent announcemerts in May, and the other two malled in October. 
Table 3. Existing Program Data by State

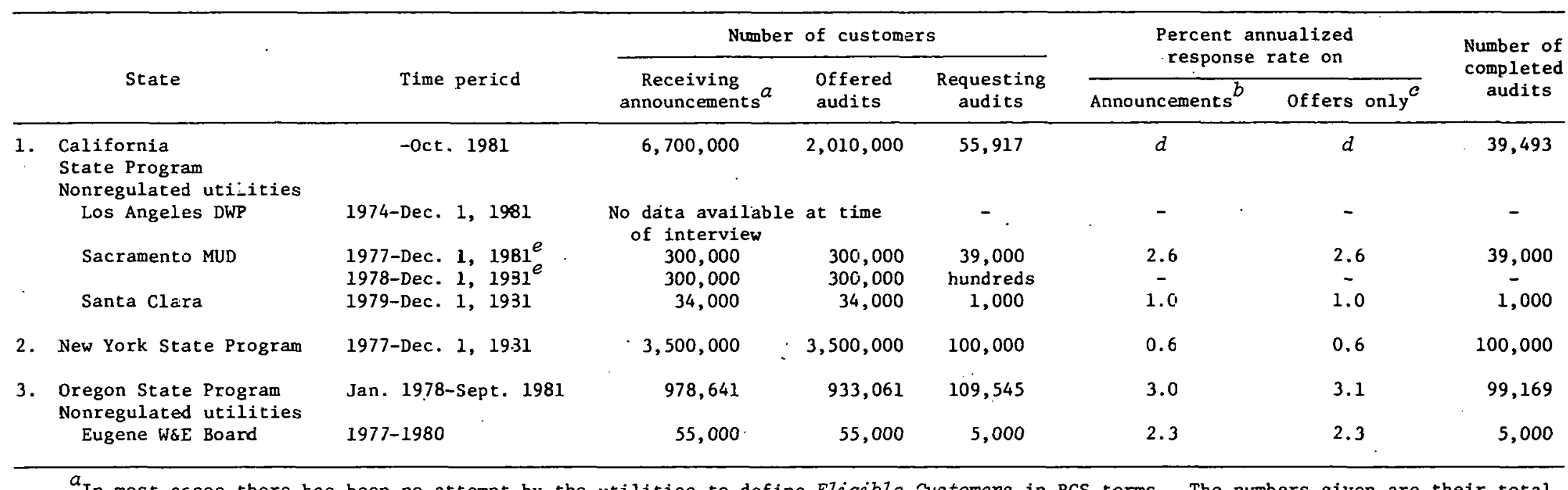

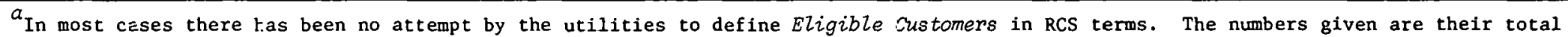
resi-lential customers and include multifamily residences, all of whom receive the program announcement.

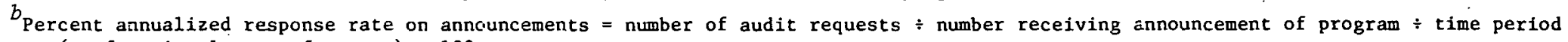
in years (or fractional part of a year) $\times 100$.

${ }^{c}$ Percent annualized response rate on audit offers only $=$ number of audits requested $\div$ number audits unconditionally offered $\div$ time period in years (or fzactional part of a year) $\times 100$.

Not annualized because time period is unknown.

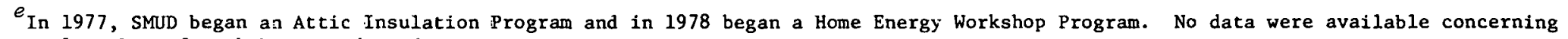
the actual number of workshops conducted. 
rather than those customers who have been actually offered unconditional audits, when there has been a difference. Both methods of calculation are represented in Tables 2 and 3* for comparison. These response rates differ because the program announcements distributed by some States and nonregulated utilities offered audits only on a conditional basis. Unconditional audits would be offered over the next two years to smaller segments of their residential customers as allowed in Section 456.306(a)(5)(i) of the original RCS Rule. Section 456.307(b), however, requires utilities to provide an audit upon the customer's request within a reasonable time, thereby placing no restrictions on when a r.ustomer may request an audit'.

In other words, the date the progran announcements were distributed has been used to establish the starting date of program operation as well as the date of llie audit offer for the purposes of this report. Some entities believe that the number of customers receiving the initial program announcement equals the number of customers eligible for the audit. However, several of the entities contacted calculated their response rates by dividing the number of requests by the number of unconditional offers, resulting in larger percentages when the size of the population which had been offered audits unconditionally was a segment of the whole as mentioned above. This lattcr approach is the preferred method of calculating the response rate.

The annualized customer response rates to the audit offer vary grcatly from State to stace and appear to ohow no sorrelation to the number of years or months that the iudividual programs have heen in operation. Tubles 2 and 3 illustrate the response rates in detail.

A few residential audit programs have been in existence for the last eight years. The response rate range among just the five-year-old programs varies from 0.6 to $2.6 \%$, annualized. For RCS Programs in operation less than one year, the customer response rates range from

* Table 2 represents data on programs that are officially RSC Programs for States and utilities with approved RCS Plans. Table 3 represents data on programs that were in existence prior to RCS as in California and Oregon, or programs in States which do not yet have approved RCS plans, as New York. 
0.03 to $11.7 \%$, annualized. Such wide ranges in response rates could be misleading in any comparison of programs unless all the factors which might affect the rates are established and considered in the comparison.

As previously mentioned, response rates were calculated by dividing the total number of customers receiving program announcements into the total number of customers who had requested audits. These figures were then annualized by (1) either upgrading the response rates of programs in operation less than one year or (2) retrograding the response rates of programs in operation longer than one year to reflect a response rate per year. For example, Sacramento Municipal Utility District (SMUD) announced its RCS Program in July 1981. At the time SMUD was contacted, the program had been in operation for five months and had received 530 audit requests from a population of 40,000 electric customers. Using the above methodology, SMUD's annualized response rate is therefore $3.2 \%$ [(530 divided by 40,000) $\times(12$ divided by 5$) \times 100]$.

When only a segment of customers is offered an unconditional audit, the response rate does not reflect a free response within the whole population of customers. The response is instead a managed response, governed by the utility's criteria for making the offer available to only that particular group. For example, if the segment chosen is in a high-income area as opposed to a low-income one, a greater response to the audit offer has been noted, indicating the possibility that the availability of financing for the retrofit action may be a prime factor in the initial response to the audit offer. When this segmental approach is used and all residential customers have not yet been offered unconditional audits, the response rates should be qualified by the demographics of the population segment. Until such time as all residential customers have been offered unconditional audits, the response rates reported on the basis of one or more segments may in reality be measuring the utility's level of resources (e.g., number of available auditors) or preference (e.g., for higher-income customers more likely to take action), rather than reflecting the interest and concern of the general population for energy conservation retrofits. 
When the audit programs have been in operation for several years, annualizing the customer response rate is again misleading. Annualizing the rates assumes that the response rates do not change over the life of the program. People who have experience with public programs have suggested that the rates may, in fact, increase in the first year, reach a steady level, and then decrease over the next two. Therefore, the data should be studied and calculated for each year of program operation, rather than annualized over the life of the program. Because of the possibility of marked variations from year to year or portions of years, response rate comparisons should be made of programs that have been in operation during the same time frame and that have targeted similar populations. Differences emerging in the response rates under these similar circumstances would be meaningful. 


\section{PROGRAM OVERVIEW OF TARGETED STATES}

\subsection{INTRODUCTION}

Several facets of the RCS Programs and other residential audit programs in operation frequently demonstrate common experiences, problems, and treatment. This section relates these commonalities.

The information obtained from contacts has been tabulated. Table 4, Residential Audit Program Data by State, offers an overview of residential audit program history (RCS and non-RCS). The table includes the number of covered utilities participating in the State-developed plan, the nonregulated covered utilities that are operating their own programs, the period covered by "existing" programs,* the dates program announcements were mailed (the initiation of RCS Programs) and audits offered unconditionally, ${ }^{\dagger}$ the audit costs charged directly to the requesting customer, and the status of the utility regulatory authority [in most cases, the Public Utility Commission (PUC) or the Public Service Commission (PSC)] concerning utility cost allocation. Nonregulated utilities are governed by local municipal boards, and all of the nonregulated utilities contacted indicated their governing boards had allocated funds to cover their RCS costs. Table 2, RCS Program Data by State, indicates the annualized customer response rates following the audit offer either contained in the program announcements or made unconditionally, frequently at a later date as a bill stuffer or in a media advertising campaign. Table 2 lists dates of program onset; annualized response rates; the number of audits completed; and the number of customers who (1) received program announcements, (2) received unconditional audit offers, and (3) requested audits. Table 3, Existing Program Data by State, has the same information for other or existing residential audit programs.

\footnotetext{
"Existing" in this context means non-kCS on-site residential audit programs, either predating RCS or ongoing.

' In the RCS Program, two types of audit offers may be made. A conditional offer is an offer preconditioned by the utility to a limited population segment, neighborhood, or time period. An unconditional offer is an offer to conduct an audit at any time upon request by an eligible customer.
} 
Table 4. Residential Audit Program Data by State

\begin{tabular}{|c|c|c|c|c|c|c|c|}
\hline & State & $\begin{array}{c}\text { Total } \\
\text { number of } \\
\text { covered } \\
\text { utilities }\end{array}$ & $\begin{array}{c}\text { Period covered by } \\
\text { existing conservation } \\
\text { program }\end{array}$ & $\begin{array}{c}\text { RCS Program } \\
\text { announcements } \\
\text { mailed }\end{array}$ & $\begin{array}{l}\text { First RCS } \\
\text { unconditional } \\
\text { audits of fered }\end{array}$ & Audit charge to customer & $\begin{array}{l}\mathrm{PUC} / \mathrm{PSC} \\
\text { ruling on } \\
\text { expensing } \\
\text { RCS costs }\end{array}$ \\
\hline \multirow[t]{8}{*}{1.} & $\begin{array}{l}\text { California } \\
\text { State Program } a \\
\text { Nonregulated utilities }\end{array}$ & 13 & Variable-Dec. 1974 & July 1981 & July 1981 & None (existing program) & - \\
\hline & Anaheim & - & $\mathrm{N} / \mathrm{A}$ & Nov. 1981 & Jan./Feb. $19 B 2$ & None (RCS) & $\mathrm{N} / \mathrm{A}$ \\
\hline & Los Angeles DWP & - & 1974-Dec. 1981 & Oct./Nov, 1981 & Oct. 1981 & None (e:ther) & N/A \\
\hline & Modesto Irrigaticn Dist. & - & $N / A$ & July 1981 & Not yet & None (RCS) & $\mathrm{N} / \mathrm{A}$ \\
\hline & Palo Al to MU & - & $\mathrm{N} / \mathrm{A}$ & July 1981 & Not yet & None (RCS) & $\mathrm{N} / \mathrm{A}$ \\
\hline & Riverside PUD & - & $N^{\prime} \mathrm{A}$ & Oct. 1981 & Jan. 1982 & None (RCS) & N/A \\
\hline & Sacramento MUD & - & 1977-Dec. 1981 & July 1981 & Sept. 1981 & None (either) & $\mathrm{N} / \mathrm{A}$ \\
\hline & Santa Clara MEU & - & 1979-Aug. 1981 & Aug. 1981 & Jan. 1982 & None (either) & N/A \\
\hline 2. & Connecticut & $?$ & $\mathrm{~N} / \mathrm{A}$ & Early 1980 & Early 1980 & $\$ 10$ (RCS) & Rate based \\
\hline 3. & Delaware & $i$ & $\mathrm{~N}, \mathrm{~A}$ & Mar. 1981 & Mar. 1981 & None (RCS) & Rate based \\
\hline 4. & Iowa & 10 & $N_{\prime}^{\prime} A$ & June 1981 & Jure 1981 & $\$ 15$ (RCS) & Not yet \\
\hline 5. & Michigan & 12 & $\mathrm{~N} / \mathrm{A}$ & June 1981 & June 1981 & $\$ 10$ (RCS) & Surcharge $^{b}$ \\
\hline 6. & New Jersey & 7 & NiA & Mar. 1981 & Mer. 1981 & $\$ 10-15$ (RCS) & Not yet \\
\hline 7. & New York ${ }^{a, c}$ & 10 & 1977-Dec. $\quad=981$ & RCS Plan not & yet approved & $\begin{array}{l}\text { None since } 7 / 81 \text { (existing } \\
\text { program) }\end{array}$ & - \\
\hline \multirow[t]{2}{*}{8.} & $\begin{array}{l}\text { Oregon } \\
\text { State Program } a, c\end{array}$ & 6 & 1978-Dec. 1981 & Not yet & Not yet & $\begin{array}{l}\text { S15 (RCS) } \\
\text { None (existing program) }\end{array}$ & Not yet \\
\hline & $\begin{array}{l}\text { Nonregulated utilities } \\
\text { Central Lincoln PUD } \\
\text { Eugene W\&E Board }\end{array}$ & - & ${ }_{1977-1981^{N / A}}$ & $\begin{array}{l}\text { Apr. } 1981 \\
\text { Apr. } 1981\end{array}$ & $\begin{array}{l}\text { AFr. } 1981 \\
\text { Apr. } 1981\end{array}$ & $\begin{array}{l}\text { None (RCS) } \\
\text { Mone (either) }\end{array}$ & $\begin{array}{l}\mathrm{N} / \mathrm{A} \\
\mathrm{N} / \mathrm{A}\end{array}$ \\
\hline 9. & Rhode Island & 10 & Niti & Jan. 1981 & Jan. 1981 & Done $(\mathrm{RCS})^{d}$ & Rate based \\
\hline \multirow[t]{2}{*}{10.} & $\begin{array}{l}\text { South Carolina } \\
\text { State Program } \\
\text { Nonregulated utilitïes }\end{array}$ & 4 & Nis & May 1981 & May 1981 & $\$ 5(\mathrm{RCS})$ & Not yet \\
\hline & Santee Cooper & - & N/e & Apr. 1981 & Apr. 1981 & $\$ 10(\mathrm{RCS})$ & $\mathrm{N} / \mathrm{A}$ \\
\hline 11. & Texas & 22 & N/A & May/Sept. 1981 & May/oct. $1981^{e}$ & $\$ 15$ (RCS) & $\begin{array}{l}\text { Gas }^{f} \\
\text { Electric- } \\
\text { rate based }\end{array}$ \\
\hline
\end{tabular}

${ }^{a}$ States of fering on-site audits in existing program.

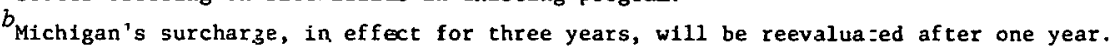

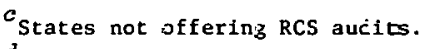

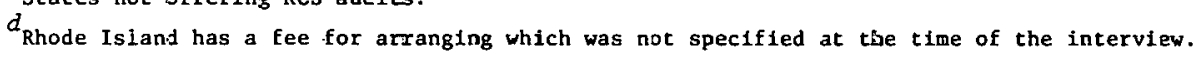

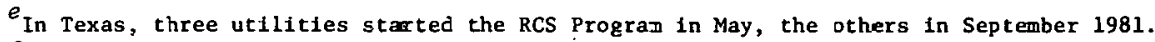

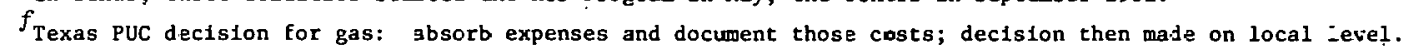


In some cases, information could not be included in the tables without citing certain limitations or qualifiers as identified by the data sources. Most of the footnotes refer to variances in identifying the number of eligible customers. For example, in Michigan the number of eligible customers quoted by the agency official has been adjusted to eliminate duplication of program coverage caused by overlap of utility service areas. Therefore, it is not the same number that would be obtained if the eligible customers of all covered utilities were combined.

\subsection{RCS AND EXISTING PROGRAMS OVERVIEW}

All of the States and nonregulated utilities contacted have RCS Programs or other on-site residential audit programs either in the initial stages of implementation or already in progress for some time (Table 4). Ten of the States contacted have DOE-approved RCS Plans. One State, New York, does not; however, New York has had an audit program in operation since 1977.

Utilities in California, Connecticut, Delaware, Iowa, Michigan, New Jersey, Rhode Island, South Carolina, and Texas have officially started their RCS Programs. Covered utilities in two States, New York and Oregon, have not started their RCS Programs although they are actively implementing other well-established audit programs.

The ten nonregulated utilities that are not participating in State programs have DOE-approved RCS Plans and have initiated their RCS Programs. Some of these utilities (Sacramento Municipal Utility District, Santa Clara Municipal Electric District, Los Angeles Department of Water and Power in California, and Eugene Water and Electric Board in Oregon) also have other residential audit activities in progress. All of the programs are discussed individually by state in sect. 4 of this report.

Five of the State agencies having regulatory authority over the regulated utilities have ruled on ways the utilities may expense RCS costs. At the time the participants were contacted, six regulatory agencies were still undecided. Two of the six State Programs are on hold awaiting this decision, but four RCS Programs have been started without it. The two States which are not implementing RCS have alternative 
conservation programs well in place. The governing bodies of all ten of the nonregulated utilities have decided on how to allocate program costs and have directed the utilities to begin their programs. Eighteen of the total twenty-six separate conservation programs are only a few months old, and seven are a few years old, with the oldest program having been in operation for approximately eight years (Table 4). These older programs have, in many cases, been modified to conform to RCS requirements.

The annualized response rates range from 0.03 to $11.7 \%$. These percentages are not directly comparable hecause the method used to calculate the response rates varied. Based on the total of more than 24,526,312 RCS announcements sent out and a total of 327,517 RCS audits requested, the overall customer response rate is approximately $1.34 \%$, which is not an annualized percent but cumulative to December 1, 1981. Annualized, this response rate averages $3.2 \%$. Based on the smaller total of more than 11,603,165 unconditional audit offers, the overall customer response rate is approximately $2.82 \%$, which again is not an annualized percent but cumulative to December 1, 1981. Annualized, this response rate on unconditional audit offers. averages $7.1 \%$.

Most of the utilities in these eleven States were artively involved in loan programs for their customers wanting to finance their retrofits. Any known details of these programs are discussed in the individual State sections. Only a few details were availahle nn utility supply and installation activities and RCS costs and budgets.

It was interesting to note the variety of charges to the customers, ranging from $\$ 0$ to $\$ 15$ for audits and $\$ 30$ to $\$ 35$ for inspections, and to the utilities for services other than audits. (See Table 4 for audit charges.) The individual State sections detail specific charges. As pointed out in Table 1 , the amendments to NECPA restrict the amount that can be charged to a customer to a total of $\$ 15$, meaning the sum of any charges for audit, arranging, etc., must not exceed $\$ 15$. The law does not address charges to the customer for inspecting, and some States charge as much as $\$ 35$ per inspection, in addition to any building permit fee a customer might have to pay. Texas charges both $\$ 15$ for an audit and $\$ 35$ for an inspection. California charges both contractors and utilities for its listing services. These charges to the utility are based on the degree of complexity of the request. 


\subsection{ARRANGING AND LISTING}

Arranging and listing are discussed as a unit because of their interrelationship. Several of the States and utilities expressed problems with the development of the RCS Master List. In some areas, contractors, lenders, and suppliers were reluctant to be included on the lists. This situation resulted in lists which contained no entries for certain areas or were so small as to be misleading. In one State, problems with the contractors, lenders, and suppliers lists were addressed by the addition of a one-page generic list of suggestions on how to choose a contractor, what to look for in a contract, and other similar issues.

From the data reported, few, if any, customers have availed themselves of the utility arranging services. In many cases, the arranging service stopped at the point when the customer received the list. Utilities interviewed had little or no data on the number of installations or financing through outside lenders arranged for their customers. Interviews need to request information on how the arranging services are promoted and explained to the customer.

\subsection{POST-INSTALLATION INSPECTIONS}

In a majority of the States contacted, the covered utilities are responsible for conducting the post-installation inspections. However, problems have arisen concerning the lack of notification to the utility by either the eligible customers or the contractors about job completions which might result in inspections. In situations where the utility has provided the financing for the retrofit activity, the utilities consider the inspections as safeguards for themselves as well as their customers. In some instances, the utility regulatory authority has required utilities with financing programs to inspect all financed installations. In both cases, inspections will not be affected by elimination of the inspection requirements in the Final RCS Rule.

Among the nonregulated utilities with their own RCS programs, few utilities perform the inspections themselves, but instead use local building code inspectors or subcontractors. Three of the programs had 
just recently been initiated and were not to the stage of inspections. Whatever the original intent regarding inspections, there is now marked uncertainty as to how nonregulated utilities will treat inspections in their programs once the new RCS Rule is published.

\subsection{INCENTIVES}

- From the interviews, the fact emerged that certain incentives included as part of the program became key factors in encouraging customers to participate initially and later take action. Programs which added incentives such as free water heater wraps or shower head restrictors were invariably impacted by these additions. The impacts most often demonstrated were increased customer response rates and pusitive attitudco by the customers towards the utility and the program.

Other additunal incentivcs were noted: (1) utility programs offering below-market or zero-interest loans, (2) audits in which a personal touch was added such as the auditor installing some energy-saving item at the time of the audit, (3) auditors who were especially personable and took the time to answer all the customer's questions, (4) postinstallation inspection programs that were fairly comprehensive (in that all items retrofitted into a home were inspected), and (5) arranging services that were vigorously promuted.

Any effort to monitor RCS progress and effectiveness needs to include questions which will identify the various aspects of State and utility programs that are included as incentives for customers to retrofit. Information on such additions to a program elucidates more about the general attitude toward the program both from management and possible customer perspectives than do the questions which only show compliance with the 1 aw.

\subsection{SUMMARY}

A brief summary of high points from the program overviews is offercd here. All eleven States and the ten nonregulated utilities contacted have conservation programs in place, either RCS or a similar on-site residential audit program. 
Several of the people contacted pointed out that the socioeconomic characteristics of the population segments that were offered the audits played a major role in determining the program response. The degree of difficulty in defining eligible customers and the difference in response due to varying stages of implementation must also be taken into account.

Several important program additions, or customer incentives, were identified. These will be discussed in the State-by-State analysis. It also became apparent that any attempt to obtain information about program status from either state agencies or the nonregulated utilities was hindered by the newness of the programs and the lack of data collection activities by the program participants. 


\section{STATE-SPECIFIC FINDINGS}

\subsection{INTRODUCTION}

This section discusses the findings of the interviews on a state-byState basis for each of the eleven States contacted. Although the thrust of this effort was to collect quantitative data about the status of implementation of the RCS Programs, information was also collected about nonRCS residential audit programs. This information has been tabulated in Tables? and 3 and is discussed in the text of this section.

Identical information was sought frum both the state lead agencies and the covered nonregulated utilities operating their own RCS Programs (Appendix A). The program elements reported varied according to the specific information collected by the people contacted. Because many of the programs have not been in operation for any significant length of time, data were not uniformly available for some activities.

\subsection{CALIFORNIA PROGRAM STRUCTURE AND STATUS}

The State lead agency for California is the California Energy Commission ( $C E C)$. The CEC has five full-time equivalent employees at present for RCS, but this will be reduced to three employees later on. Costo to be incurred for planning, implementing, and operating the RCS Program are budgeted as follows: $\$ 175,000$ for salaries; $\$ 100,000$ for contract for delisting; $\$ 50,000$ for master listing; $\$ 5,000$ for quarterly updating of prices used to base the savings estimates; $\$ 100,000$ for uverhead; and $\$ 200,000$ over the next four years to support the twelve small municipal ntilities that have joined the State RCS Program. The RCS Plan developed by CEC has been approved by DOE. At the time of the interview the California Public Utility Commisston (PUC) had not ruled on how the nine covered utilities may allocate their RCS costs. Rulings are expected to begin clearing the PUC in January 1982. The CEC stated that the PUC was expected to reduce the funding requested by each regulated utility. Five nonregulated covered utilities have elected to participate under the auspices of the California State Plan; seven nonregulated utilities 
have chosen to develop and implement their own programs (Appendix $B$ ). In addition, thirteen noncovered publicly owned utilities will participate in the State program (Appendix B). Home-heating suppliers are not participating in the program.

The State RCS Program, begun in 1981, is an outgrowth and refinement of an existing program, making it difficult to pinpoint an exact starting date. The arranging services, particularly the use of the lists, has been specifically added. Individual utilities have been involved in on-site residential audit programs for several years. Actual initiation of the RCS Programs in some cases could not be distinguished from these ongoing programs. Where start-up dates were identified, they varied individually with each utility. (See Table 2 for information concerning start-up dates.) There are approximately 6.7 million customers eligible for RCS participation statewide. For the RCS Program, there is no direct charge to the requesting customer for program services. Tables 2, 3 , and 4 list this information.

At the time of the interviews, data were available for only the four-month period of July through October 1980. Using the previously discussed method of calculating response rates, the annualized response rate across the State is $2.1 \%$ for this period.

Firms 1isted on the Master. Record as contractors, suppliers, and/or lenders are charged $\$ 25$ for the initial listing and $\$ 5$ annually to be relisted. Utilities are assessed a fee for computerized retrieval of the list in whatever format they specify, the charge being based on the complexity of their request. The CEC has subcontracted the listing functions to a third party, LRS and Company: The contract date is July 1, 1982, and all present charges are subject to change at that time. If the contract is not renewed, the utilities will assume the handling of the listing updates and their costs. Presently, a paper printout to a utility with a small service area costs that utility $\$ 25$. For utilities requesting information on magnetic tapes, the charges are about $\$ 400$ for a large service area and about $\$ 150$ for a small service area, averaging approximately $\$ 381$. 
Several utilities operate financing programs, charging anywhere from no interest to $8 \%$. The financing is available predominantly for insulation installation, although other weatherization materials are sometimes included in the programs. The State utility regulatory authority requires inspections of all utility-financed retrofits. Local building code officials will be used to inspect installations that have not been financed directly by the utilities.

\subsubsection{Nonregulated Utility Programs}

Seven covered nonregulated utilities are operating RCS Programs independently from the State program. They are the Anaheim Electric Division, Los Angeles Department of Water and Power, Modesto Irrigation District, Riverside Public Utilities, Sacramento Municipal Utility District (SMUD), Santa Ciara Electric Deparcment, and Palu Allo Electilc Utility.

All seven of these utilities have started their RCS Programs. Taking the newness of the programs into account, the annualized response rates range from 0.03 to $7.0 \%$ (Table 2). Three of the utiliites, Los Angeles, SMUD, and Santa Clara, have had other residential audit programs in place for several years; the earliest started in 1974. The annualized response. for these existing programs range from 1.0 to $2.6 \%$ (Table 3 ). There is no direct charge to the requesting customers for audits in any of the programs.

Santa Clara, Modesto, and SMUD have entered into joint programs with the Pacific Gas and Electric Company (PG\&E) where their service areas overlap. These nonregulated utilities will provide program services to only those customers who have electric space heating. In these three areas, PG\&E will audit only customers with gas-heated homes. The total number of residential customers has been adjusted by these three utilities to reflect this dual coverage of approximately $80 \%$ of their customers (Table 2).

When customers are serviced by both utilities, Santa Clara Municipal Utility District refers these cutomers to PG\&E so that they may take 
advantage of PG\&E's loan program. The interest rates charged on these loans are $8 \%$. SMUD has its own financing program, which is similar to that of PG\&E. Additionally, SMUD operates a leasing program for solar water heating equipment for domestic water heaters and swimming pools. There are currently 250 participants in this solar program.

Palo Alto has a loan program geared towards the installation of active solar systems. The interest rate charged is $8 \%$ with a maximum amount of $\$ 3,500$ allowed for single-family homes. A loan program for attic insulation has also been started, with an upper limit of $\$ 550$. Palo Alto recorded that of the 37 customers who had attic insulation installed after the start of its loan program, $43 \%$, or 16 customers, have used the utility's financing. These 16 customers borrowed an average of $\$ 450$ to $\$ 500$ per installation. Los Angeles has a loan program with $7.25 \%$ interest rate for solar water heater and heat pump water heater retrofits. The maximum amount that can be borrowed is $\$ 10,000$ for a single-family home.

Most of the utilities have arranged to use the list of contractors, suppliers, and lenders prepared by CEC. The utilities themselves will handle any inspections.

\subsubsection{Unique Features}

Starting in January 1982, the audit procedures used by the utilities operating under the State program will be somewhat simplified. The audit results presentation will always include standardized recommendations for the addition of wall, attic, and floor insulation, and insulating window coverage, if not already present in the home, rather than the auditor performing these calculations and measurements specific to that residence. Auditors found that they were recommending these measures in nearly every home, and therefore standardizing the calculations for these items will reduce the time spent on each audit.

One utility, Pacific Power and Light Company (PP\&L), offers its customers comprehensive services for retrofit installations, including zero-interest loans. After having an audit, the customer may sign an agreement which ohligates PP\&I to arrange contracling, financing, and 
inspection. SMUD offers subsidies based on income level for conservation installations. Several other utilities will continue to offer zero- or low-interest loans that were part of existing programs and are now in conjunction with RCS activities. PG\&E will continue offering zerointerest loans in their San Joaquin program and $8 \%$ interest loans in the rest of their service areas on ceiling and floor insulation installations. For the same type of installations, San Diego Gas and Electric, Southern California Gas, and Southwest Gas Corporation will continue offering $8 \%$ interest loans, and Southern California Edison will continue its zerointerest loans. Sierra Pacific Power will also continue with an interest rate of $8 \%$ on its insulation loans.

\subsubsection{Problems and Impacts}

Une of Callfornia's most oignificant prohlems in attempting to implement the RCS Program has been the development of the Master Record and the listing requirements. The CEC reports that many installers are unwilling to be included because they feel the listing requirements duplicate the requirements of the California Contractors' State License Board. The CEC also reported that the contractors feel that the 11 st causes price fixing and anticompetitiveness, is an attempt by government to regulate their industry, and/us constitutca an inappropriate utility involvement in the contracting process. The CEC is working to alleviate this negative attitude and has devised an addition to the Master Record, a nne-page generic list of suggestions on how to choose a contractor and understand the contractors' bid speciffcalion sheets.

\subsection{CONNECTICUT PROGRAM STRUCTURE AND STATUS}

The State lead agency for Connecticut is the Office of Pollcy and Management (OPM). During the first year of operation of RCS, the OPM had two full-time equivalent employees with a budgeted operating cost of $\$ 95,000$ for this program. The number of employees has fluctuated from a maximum of five to a present number of three full-time equivalent employees. The State has a DOE-approved RCS Plan encompassing seven 
utilities, two of which are participating voluntarily. There are no covered nonregulated utilities in Connecticut. Home-heating suppliers are participating on an individual voluntary basis. The Public Utility Control Division ruled that the utilities can rate-base their RCS costs. The State RCS Program began in early 1980 and is managed by CONN SAVE, which is a not-for-profit corporation formed by the utilities. CONN SAVE provides all RCS services to the approximately 844,000 eligible customers. The organization charges the customer $\$ 10$ for an audit and also provides any arranging services upon request. No arranging services have as yet been requested by the utilities' customers. There has been a response rate for audits of $3.1 \%$, annualized (Table 2).

CONN SAVE also performs the inspections and attempts to resolve any customer complaints with the contractors. Inspections are performed on all RCS retrofits of potentially dangerous systems or items such as wind systems and solar water heaters. The organization will also inspect the first ten contractor insulation installations and will inspect the installation of other measures on a sample basis. The lead agency compiles and updates the Master List, and CONN SAVE prints and distributes it. Presently, there are no utility loan programs in effect. A study is in progress to examine the feasibility of such a program.

\subsubsection{Unique Features}

The RCS Program, with the exception of the compilation of the Master Record, is totally managed and operated by the CONN SAVE organization. CONN SAVE's governing body is composed of a Board of Directors whose membership is made up of representatives of the participating utilities. A close working relationship exists between this group and the lead agency.

\subsubsection{Problems and Tmpacts}

CONN SAVE has experienced problems with contractor participation. According to one interviewee, the contractors are avoiding the program because they do not want their work to be subject to inspections. Additionally, contractors who are participating in the program are reluctant to return job completion cards, once again avoiding possible inspections. 


\subsection{DELAWARE PROGRAM STRUCTURE AND STATUS}

The Delaware Energy Office (DEO), which is the State lead agency, began its RCS Program in March 1981 with a DOE-approved plan. The DEO has two employees who work part-time on the RCS Program. Budgeted costs for the program were $\$ 15,000$. There is one covered utility in the State and no nonregulated utilities. Home-heating suppliers are not participating in the program. The Public Service Commission ruled that the covered utility should treat RCS costs as operating costs. A rate calculation will be spread out over every customer's bill.

There are approximately 160,000 eligible customers served by Delaware Power and Light Company. Delaware has had a customer response rate of $2.5 \%$, annualized (Table 2). The DEO is finding the overwhelming majority of these responses are from the higher income metropolitan districts, on the order of 5 to 1 when compared to the total rural responses. There is no charge for the audit.

Delaware's one covered utility does not have a loan program available to its customers, nor does it plan to develop a financing program for retrofits.

The DEO manages the Master Record development and updates. It has removed. two firms because of failure to maintain proper liability insurance. 'l'here have been no complaints about performance. Based on the available data, customers use the utility to help in arranging supply, installation, and/or financing after receiving the list.

Mandatory inspections are being performed by a professional inspection agency, called Middle Department Inspection Agency, for a fee of approximately $\$ 30$. If the installations require building permits, local building code officials will inspect the retrofits. The utility will conduct other random inspections.

DEO conducted a survey which indicated that $46-48 \%$ of the customers interviewed have already taken actions in retrofitting their homes as a result of the RCS Program. 


\subsubsection{Problems and Impacts}

No significant problems with implementing the RCS were reported. The lead agency and the utility have closely coordinated the program development.

\subsection{IOWA PROGRAM STRUCTURE AND STATUS}

Iowa's RCS Program, I-SAVE (Iowa Saves America's Vital Energy), is administered by the Iowa Commerce Commission (ICC). The ICC is the appointed State lead agency and is also the State's regulatory authority for the ten covered utilities operating under the DOE-approved RCS State Plan. There are no nonregulated utilities covered in the program. Participation of home-heating suppliers is confined to installations of furnaces and furnace modifications. The ICC has one full-time employee working on the RCS Program. Costs incurred from September 1980 through March 1981 were approximately $\$ 84,000$.

In June 1981 Iowa began the RCS Program and completed the mailing of program announcements to approximately 1.4 million eligible customers. Tables 3 and 4 list data for audit offers, requests, etc. Iowa reported that of the 331,792 audits offered, $4,214(1.27 \%)$ were completed by December 1981. The annualized response rate based on the total number of eligible customers is $0.7 \%$. There has been no ruling as yet from the ICC on how the RCS Program costs will be expensed.

Arranging, listing, and inspecting services have received little interest from consumers. Few requests have been made to date. Iowa's RCS Program requires utilities to be the lenders of last resort for loans up to $\$ 1,000$. Utilities are contesting this ICC order and have not yet established loan programs.

The utilities perform the inspections on retrofits. Of the 4,800 audits completed, 13 inspections have been performed on insulation and vent damper retrofits (figures updated February 4, 1982). To have an inspection performed, a customer must have requested one of the arranging services offered by a utility. One utility has randomly called their audited customers and offered to inspect any retrofit they have installed. 
Of the 13 inspections to date, 10 were performed by. this utility, other inspections have been done at the customer's request. No irregularities have been reported from any of these 13 inspections.

\subsubsection{Unique Features}

The I-SAVE program is a cooperative effort between the participating utilities and the ICC. This joint effort has allowed for smooth implementation of the program.

\subsubsection{Problems and Impacts}

No significant problems were reported. There is, however, concern on the part of the utilities about the ICC order requiring them to act as lenders of last resort.

\subsection{MICHIGAN PROGRAM STRUCTURE AND STATUS}

Michigan's RCS Program is managed by the Department of Commerce, which is the appointed State lead agency. The Public Service Commission (PSC) is the utility regulatory authority for the nine utilities covered in Michigan's DOE-approved State RCS Plan. The PSC, supplying a majority of the manpower now, has four full-time employees working on RCS, and the lead agency oupplico one or two people for the purpose of ccrtifying auditors. Cost figures for program implementation are not available; however, the utilities report that each audit costs on the order of $\$ 100$ to $\$ 150$. Although listed as operating within the State, Panhandle Eastern Pipeline Company, Wisconsin Public Service, and Wisconsin Electric Power Utilities are not included in Michigan's RCS Plan. There is one nonregulated utility, Lansing Board of Water and Light, participating in the State program. Home-heating suppliers are not participating. RCS is but one of three programs Michigan has included in its Energy Saving Plan. The others are a free ceiling insulation program for low-income households and zero-interest financing program available to gas heating customers for the installation of ceiling insulation or furnace retrofits. 
Michigan began its RCS Program with the mailing of its program announcements in June 1981. Tables 2 and 3 contain data for audit offers and requests. There are approximately 6.1 million eligible customers. of the 3 million customers offered audits in the program announcements, 175,000 audits were requested and 67,000 were completed by December 1981 . The annualized response rate is $11.7 \%$. The charge for an audit is $\$ 10$. This fee is waived for low-income customers.

In determining how the RCS Programs costs should be expensed, the PSC ruled that a surcharge was to be calculated using the actual startup costs (spread over three years) and the estimated costs for the first year of operation. The surcharge is to be applied to every unit of electricity and natural gas. After one year a reconciliation. is to be made to evaluate actual versus estimated costs.

The utilities are responsible for inspecting all reported retrofit jobs. However, gas utilities inspect furnace retrofits, and wind devices are inspected by the electric utilities.

Michigan utilities make loans primarily for ceiling insulation. Some utilities charge below-market interest rates; others have interestfree loans. Zero-interest loans on ceiling insulation can be made for up to R-19 if the customer currently has less than $2 \frac{1}{2}$ inches of insulation or if the RCS audit shows a seven-year payback. Some utilities offer loans of up to $\$ 500$ for vent dampers.

\subsubsection{Problems and Impacts}

The RCS Program has been well received by the public. During the first four months of the program, the utilities had a response rate which exceeded their expectations. This high response has been attributed to full support of the major utilities and the PSC for the program, coupled with the financing programs offered by many utilities.

The PSC conducted a telephone survey to evaluate the impact of the RCS Program. This preliminary survey showed a favorable customer response to the program: The PSC also made an effort to examine the customer's image of the utility company and found that customers had a more positive image when auditors actually adjusted or installed something to save 
energy at the time of the audit, when customers felt enough time was spent on the audit, when the customer was allowed to accompany the auditor during the audit procedure, and when the auditor explained arranging services to the customer. Customer actions in conservation/renewable measures were high when the auditor was helpful in explaining ways to save energy and when the payback periods for the measures were not too long. The survey asked customers to explain what energy conservation actions had been taken or planned as a result of the audit.

Some problems were identified through this survey: (1) payback period calculations were questioned by some customers; (2) solar and wind devices seemed to the customer to have unreasonably long payback periods; and (3) some customers disagreed with the auditor's recommendations on energy conservation practices and measures in their homes. It was also noted that not all customers were informed of the arranging of financing, installation, and inspections. On 1 y $21 \%$ planned to use installation arrangement services, and $40 \%$ said they would consult the list of contractors provided by the utility. Six percent planned to use financing, and $21 \%$ planned to consult the list of lenders. About $48 \%$ of those interviewed listed financial constraints as the primary barrier to doing as much toward energy conservation as they wanted. Consequently, information on financing was listed as very important.

\subsection{NEW JERSEY PROGRAM STRUCTURE AND STATUS}

The New Jersey Department of Energy, the State lead agency, began the RCS Program with the mailing of program announcements in March 1981. The New Jersey DOE's outlay of monies for planning, implementing, and operating the RCS Program is small, basically the salaries for its four fuil-time equivalent employees. The Board of Public Utilities is the regulatory authority for the seven utilities servicing approximately 3 million eligible customers under New Jersey's DOE-approved State RCS Plan. There are no nonregulated utilities covered in the program. Approximately 105 home-heating suppliers are participating through referrals by utilities for installation of clock thermostats, furnaces, and furnace modifications. 
Tables 3 and 4 contain data detailing audit offers, requests, etc. Unconditional Class A audits at a cost of $\$ 10$ to $\$ 15$ were offered to the eligible customers. Even though no ruling has as yet been made on how the RCS Program costs will be expensed, the annualized response rate is $1.2 \%$. No data are presently available on the number of audits completed.

New Jersey has a PUC-mandated loan program for its utilities. Twelve percent loans repayable over three years for insulation and clock thermostats are being offered, with a maximum loan of $\$ 500$. As yet only six people have requested these utility loans. The low response is attributed to little or no publicity about the program.

Local building code officials and the utilities will both be responsible for conducting post-installation inspections. The building code officials will inspect retrofit jobs that require a building permit; the utilities will handle other inspections.

\subsubsection{Unique Features}

Although not currently in effect, the original intention as discussed in the State Plan was to conduct a massive multimedia campaign to publicize the program. This approach was to supplement information distributed as bill stuffers in utility mailings.

\subsubsection{Problems and Impacts}

According to one interviewee, the utilities are not actively promoting the RCS Program, nor is the State lead agency pushing for full-fledged implementation. This lack of effort was attributed to the political uncertainty surrounding the program in Washington.

New Jersey is planning to conduct a survey on RCS retrofit participation. The State lead agency would like to investigate the customers' motivations to retrofit, for audited versus nonaudited customers. The State lead agency would also like to determine what best motivates the utility to promote the RCS Program to its customers. 


\subsection{NEW YORK PROGRAM STRUCTURE AND STATUS}

The New York State Public Service Commission (PSC). is responsible for development and administration of the RCS Program. The PSC has seven full-time employees on this program. Cost distribution for the program is as follows: salary and overhead for all seven employees, $\$ 420,000$; planning and implementation, $\$ 500,000$; promotion of program, $\$ 600,000$. The PSC has ruled that the nine utilities involved may ratebase program costs to all of its customers. However, the State RCS Plan has not been approved by DOE. The PSC is therefore continuing with an existing energy conservation program. The existing program started in 1977 with legislative action, the Home Insulation and Energy Conservation Act (HIECA), to enforce it.

Over a period of four years, New York's existing program has had an annualized response rate of $0.6 \%$ for Class $A$ audits (Table 3 ). The program offers Class A, B, and C audits.* Prior to July 1981, there was a $\$ 10$ charge for a Class $A$ audit and a $\$ 3$ charge for a Class B audit. Currently there is no charge for any of the types of audits.

The PSC handles the listing of contractors and suppliers. Homeheating suppliers are invited to participate as listed contractors in the program. The PSC has required utilities to provide loans or loan arrangements through local banks for their customers wanting retrofits. These retrofits, must be energy-conserving measures with payback periods of seven years or less. The interest rates on these loans range from $y$ to $11 \%$ and are governed by the utilities' overail rate of return. The loans may be extended for up to seven years and are allowed for a minimum amount of $\$ 200$ and a maximum amount of $\$ 3,500$ for single-family dwellings. Ten percent of the utilities' customers have requested and been granted thesc loans. A majority of the customers (20-30\%) du wul fluduce their retrofit actions. Utilities inspect $100 \%$ of the retrofits for which they have provided financing.

${ }^{*}$ Class A audits are RCS-type audits in which an outsider provides an inspection of the home and does any calculations necessary. Class $B$ audits are questionnaires which the resident completes and returns to the utility for analysis. Class $C$ audits are questionnaires which are completed by the resident, who then does any calculations himself. 


\subsubsection{Unique Features}

Although fuel-switching recommendations are prohibited within the existing RCS framework, conversion of oil-fired furnaces to gas-fired ones is part of the HIECA program. Other RCS activities are viewed as a federal extension of State-mandated utility conservation efforts.

\subsubsection{Problems and Impacts}

The New York RCS Plan has not been approved by DOE. There is, however, a strong conservation ethic in the state. The utility companies have been instructed by the PSC to continue their existing programs. The interview did not elicit information concerning how or when the HIECA activities would be brought into compliance with the RCS regulations.

\subsection{OREGON PROGRAM STRUCTURE AND STATUS}

The State lead agency for Oregon is the Public Utility Commission (PUC). The PUC has a staff of one person working on RCS with costs of $\$ 30,000$ (salary) plus $\$ 10,000$ overhead. Oregon has a DOE-approved RCS Plan, but the PUC has not yet ruled on how the six covered utilities are to expense their RCS costs. Therefore, the utilities have not started RCS Program operation. However, utilities in Oregon presently are operating an alternative conservation program. This program began in January 1978 and offers a free audit to approximately 980,000 residential customers. When RCS begins, the RCS audit will be offered to approximately 393,000 eligible customers (space heating customers only) and will carry a $\$ 15$ charge, even though the two audits are the same. Tabulated data for the existing program can be found in Tables 2 and 4 . Over a period of four years, the existing State program has had an annualized response of $3.0 \%$.

In the existing program, 41,148 residential customers are known to have retrofitted their homes with various energy-conserving measures, costing an average of $\$ 1,800$ per retrofit: These retrofits were mostly for ceiling and floor insulation and storm windows. All of the retrofits were financed through utility loan programs. 
There are basically two utility loan programs. One program offers a zero-interest loan in which the utility places a lien on the customer's home. The other program carries a $6.5 \%$ interest rate; assets other than a customer's home may be used as collateral. As instructed by the PUC, electric utilities must offer their cutomers a choice of either a $6.5 \%$ loan or a cash rebate which varies according to specified circumstances. Some utilities also have the zero-interest loans available. The maximum a customer can borrow on the $6.5 \%$ loan is $\$ 4,000$; there is no maximum on the zero-interest loan. Gas utilities must offer loans with interest rates ranging from 6.5 to $12 \%$. This rate must be $10 \%$ less than the Federal Administration rate. Oregon law requires an audit as a prerequisite to the loans and cash rebates. The utilities must also offer an inspection of the retrofits to any participant who requests one. Previously, Oregon's utilities collectively inspected approximately $80 \%$ of the retrofits they financed. Pacific Power and Light and Northwest Natural Gas Company inspected $100 \%$ of financed retrofits and expects to continue this procedure. Portland General Electric and CP National Corporation inspected $50 \%$ of financed retrofits. Cascade Natural Gas Company provided inspections upon receipt of complaints. Idaho Power Company did not conduct inspections. In the future, these last four utilities will perform inspections on the first ten jobs and then $20 \%$ of future installations. On installations not covered by this policy for new contractors, they will perform inspections only upon request by the customer.

There have been approximatcly 100 to 200 customer complaints. The utilities have acted as mediating agents in customer disputes with the contractors. In the future, the customers will be expected to resolve their own differences directly with the contractor without utility mediation. Howcver, the PUC will monitor cuotomer complainto.

Under the existing program, lists are not used. However, the utilities will review the bids that customers have secured on their own. Home-heating suppliers will shortly be mandated to participate in this program. They must pay the State an assessment which will then be used to finance the home-heating suppliers audit program. The oregon Department of Energy has contracted for audit services to home-heating 
suppliers' customers; the State will manage this home-heating suppliers' audit program. Home-heating suppliers are not required to offer rebates or loans to customers who undertake retrofit actions. Therefore, under oregon law, customers of home-heating suppliers can still claim appropriate State tax credits on measures installed.

\subsubsection{Nonregulated Utility Programs}

Two nonregulated utilities, Central Lincoln People's Utility District and Eugene Water and Electric Board (EWEB) are implementing their own RCS Programs. Both have DOE-approved plans. EWEB had an established conservation program from 1977 to 1980 in which 5,000 audits were requested and completed, reflecting an annualized response rate of $2.3 \%$.

Central Lincoln and EWEB began their RCS Programs in April 1981, servicing approximately 78,000 eligible customers. Annualized response rates of $5.7 \%$ and $6.3 \%$, respectively, have been reported.

Neither of these two utilities has in-house loan programs. Both are joining Bonneville Power Administration's (BPA) loan program, which offers a choice of either a zero-interest loan or a cash rebate on as much as $80-100 \%$ of the measures retrofitted with no maximum on the amount a customer can borrow.* Thus far, neither utility has had any requests for the arranging services. Both utilities will inspect $100 \%$ of all utility (BPA) financed retrofits, and each will handle the listing of contractors, suppliers, and other lenders in their respective areas.

\subsubsection{Problems and Impacts}

On rechecking figures for EWEB, the utility officlal states that they are now (February 1982) scheduling audits into 1983. The customer response rate is overwhelming because of the tie-in with the BPA loan program for which an audit is a requirement. Apparently, customers were waiting for the loan program to start before requesting audits. Customers had been informed of the potential for $100 \%$ rebate on their

\footnotetext{
${ }^{*} \mathrm{BPA}$ operates the Energy Buyback Program in the Pacific Northwest.
} 
loans, a factor determined by the size of the investment and the energy savings accumulated after one year.

\subsection{RHODE ISLAND PROGRAM STRUCTURE AND STATUS}

The Rhode Island State Energy office is the RCS State lead agency. Budgeted costs for RCS in 1982 are $\$ 934,000$. The State Energy Office has two full-time employees on this program. A third-party corporation, RISE (Rhode Island Is Saving Energy), is supported by all the covered utilities to provide the services required by the DOE-approved State RCS Plan. There are no covered nonregulated utilities in the State. However, six noncovered utilities have decided to participate in the RISE program (Appendix B). Rhode Isiand's Public Utility Commission has ruled that the RCS costs may be included in the utilities' rate-base as a surcharge to all customers. The extent of home-heating supplier participation is limited to membership on the RISE Board of Directors in an advisory capacity.

The RISE program began in January 1981 with the distribution of program announcements to 538,523 eligible customers. The annualized response rate to date ranges from 1.8 to $2.4 \%$ for participating utilities. There is no charge for audits or arranging services. The Energy officc is responsible for developing and maintaining the Master Record. Postinstallation inspections are conducted by the member utilities and homeheating suppliers. Inspections are for all arranged installations and follow the inspection requirements of the Nnvemher 1979 Br.S Rule. Somo Inspections have revealed problems with insulation installations and burner replacement installations.

RISE operates an insulation supply and installation program. Customers may purchase insulation at a predetermined fixed cost, and RISE will install it if requested. Additionally, RISE will actively assist customers in obtaining financing for purchase and installation. 


\subsubsection{Unique Features}

The corporation which manages RISE provides a one-step service for all residential energy conservation activities. RISE uses a Statedeveloped audit. It trains and certifies auditors, provides consulting services, interfaces with contractors and suppliers, arranges financing and installation, and handles post-installation inspections.

\subsubsection{Problems and Impacts}

A problem exists to some extent in that utilities have no way of separating the number of multifamily units from the number of single or less-than-five family units. Using census data, the lead agency reports that the total number of dwelling units equals 330,000 and therefore estimates their total number of eligible customers to be about 300,000 . Their reported response rates of $3-4 \%$ were based on this smaller number.

\subsection{SOUTH CAROLINA PROGRAM STRUCTURE AND STATUS}

South Carolina's RCS Program began in the spring of 1981 with an intensive promotional effort originating from the Governor's Division of Energy Resources (DER), which is the State lead agency. The DER has two full-time employees on RCS. Costs to date including training programs and program spinoffs are $\$ 150,000$ ( $\$ 75,000$ per annum). The program covers four regulated utilities. United Cities Gas Company petitioned for exemption from the RCS Program. South Carolina Public Service Authority (Santee Cooper) is the State's one nonregulated utility and has chosen to implement a separate RCS Program. Both the State and Santee Cooper have DOE-approved RCS Plans.

The Public Service Commission (PSC) for South Carolina has not yet ruled on how the RCS costs will be expensed by the utilities involved. Nevertheless, the RCS Program is in progress and has begun to experience responses from the approximately three-quarters of a million customers at an annualized rate of $0.6 \%$. Tabulated data for South Carolina can be found in Tables 3 and 4 . The State program includes both Class $A$ and $B$ audit offers. (See the footnote in sect. 4.8 for definitions of 
Class $A$ and $B_{\text {.) }}$ The requests for Class $B$ audits have been almost twice as great as the requests for Class A audits, which cost the customers $\$ 5$ each.

Only one utility offers an, in-house supply, installation, and loan program. Piedmont Natural Gas Company (PNGC) has offered this program since 1968 and has incorporated it into its RCS Program. PNGC sells and installs insulation, storm doors, storm windows, and solar water heaters and offers loans for installation with repayment over one to three years. The interest rate varies with the amount of the loan. Loans under $\$ 3,000$ are financed at a rate of $17.92 \%$, loans over $\$ 5,000$ at a rate of $13.95 \%$, and amounts between $\$ 3,000$ and $\$ 5,000$ at a rate of $16 \%$.

The DER is handling the listing of installers, suppliers, and lenders.

\subsubsection{Nonregulated Utility Program}

Santee Cooper has promoted the conservation of energy to its customers since 1960 by encouraging them to install insulation, storm or insulated windows, water heater wraps, and heat pumps (in all-electric homes for the latter only). The more comprehensive RCS Program began in April 1981 with the distribution of the program announcements. As of the date of the interview, approximately 50,000 customers have been offered unconditional audits. The annualized response rate ranged from 1.0 to $1.4 \%$, depending on the figures used.

Santee Cooper has developed its own Master Record. It is also responsible for conducting post-installation inspections in its service area. None has been performed as yet.

\subsubsection{Problems and Impacts}

Comments received concerning the usefulness of the lists are generally negative in nature. In some instances the lists are felt to he so large that they are no better than the yellow pages of the telephone book. Some contractors claim to service all areas within several hundred miles of their offices. In discussions with several utilities, the RCS 
arranging services, which these lists are intended to promote, do not appear to be generating much interest from the customers. Also, the DER does not request data on arranging from its utilities, nor have the utilities really begun to keep track of requests for help with bids or loan arrangements.

The DER has qualified one person to perform inspections, but this aspect of the program has been placed on hold until the new Proposed RCS Rule is final. It is unlikely the DER will pursue its original design if the new rule does not specifically require these elements.

\subsection{TEXAS PROGRAM STRUCIURE AND STATUS}

The RCS Program in Texas is under the direction of the Texas Energy and Natural Resources Advisory Council (TENRAC), which has one full-time RCS employee at TENRAC. Costs to develop the RCS Program to date are $\$ 75,000$. The two utility regulatory authorities, the Railroad Commission and the Public Service Commission, have both ruled on how their respective utilities may expense the RCS costs (Table 4). TENRAC has a DOE-approved RCS Plan which includes all the covered nonregulated utilities in the state.

A11 but one utility sent out program announcements for RCS in the fall of 1981. El Paso Electric Company mailed them in May 1981. Most of the utilities have plans to offer unconditional audits in January 1982. Audit costs will range from $\$ 5$ to $\$ 15$ to the requesting customers. Three utilities made this offer in their program announcements and have, as a result, already received requests for audits from their customers. Response rates (Table 2) were calculated for these three utilities as well as the State as a whole. The other utilities do not report having received any requests as yet. The overall annualized response rate for the State is $0.03 \%$.

Post-installation inspections for the program will be conducted by the Texas Department of Labor and Standards. New legislation allows this department to perform this function and collect fees to recover expenses for this service. The charge to a customer will be $\$ 35$ per inspection. 


\subsubsection{Problems and Impacts}

There have been unavoidable delays in starting the RCS Program as a whole. A main problem was in preparing the Master Record. As of the date of this interview, there were only 30 people who had agreed to be listed. TENRAC plans to develop strategies to overcome the lack of enthusiasm on the part of the contractors. 


\section{APPENDIX A - \\ INTERVIEW GUIDE}

1. Number of covered utilities in your state
a. New
b. Exempt

2. Number of residential customers

3. Number of eligible customers

4. Have you mailed Program Announcements? (RCS or other program)

5. When?

6. Does it offer unconditional audits?

7. Number of eligible customers offered Class A unconditional audits 8. When?

9. Number of eligible customers who have requested audits 10. When?

11. How many of the audit requests have been completed?

12. What has been the response rate to the program?

13. How was this number calculated?

14. Is there an audit charge to the eligible customer directly?

1.5. How much?

16. Are there any other direct charges to the eligible customer?

17. Which utilities have in-house supply, installation, and/or loan programs?

18. Number of eligible customers who have used the utility loan programs

19. Maximum amount the eligible customer can borrow from the utility 20. Average amount of loan 
21. Interest rate charged
22 . What measures does the utility supply or install?

23. Number of eligible customers requesting arranging of installation and/or financing

24. During what time period were these requests made?

25. Who conducts post-installation inspections?

26. Number of inspections completed

27. What irregularities have been reported?

28. What agency is responsible for preparing the list of suppliers and lenders?

29. How?

30. Number of participating home-heating suppliers

31. Type of participation

32. Has the State regulatory authority ruled on utility allocation of RCS Program custs?

33. What was the decision?

34. What costs were incurred by the State lead agency (SLA) for planning, implementing, and operating the RCS Program?

35. Number of full-time equivalent SLA employees working on RCS

36. Does your State or utility program have any unique or special features such as loan subsidies or third-party corporations?

37. Have any follow-up surveys been done concerning retrofit actions taken, satisfaction or usefulness of the audit or arranging services, etc?

38. How was the survey data collected?

39. What was the population used in the survey? 
40. If survey has been completed,

a. number of retrofit actions taken

b. average cost of the retrofit

c. which measures were installed

41. Please send a copy. 
APPENDIX B

PROGRAM COVERAGE

\begin{tabular}{|c|c|c|c|c|}
\hline \multirow[b]{2}{*}{ Utilities ${ }^{a}$} & \multirow{2}{*}{$\begin{array}{l}\text { Covered } \\
\text { regulated }\end{array}$} & \multicolumn{2}{|c|}{$\begin{array}{l}\text { Covered } \\
\text { nonregulated }\end{array}$} & \multirow{2}{*}{$\begin{array}{l}\text { Noncovered } \\
\text { voluntary }\end{array}$} \\
\hline & & State & Independent & \\
\hline \multicolumn{5}{|l|}{ CALIFORNIA } \\
\hline $\begin{array}{l}\text { Alameda Bureau of } \\
\text { Electricity }\end{array}$ & & & & $\mathrm{X}$ \\
\hline Anaheim, City of & & & $\mathrm{x}$ & \\
\hline Berkeley, City of & & & & $\mathrm{x}$ \\
\hline Biggs Municipal Utilities & & & & $\mathrm{x}$ \\
\hline $\begin{array}{l}\text { Burbank Public Service } \\
\text { Department }\end{array}$ & & $\mathrm{X}$ & & \\
\hline CP National Corporation & $\mathrm{X}$ & & & \\
\hline $\begin{array}{l}\text { Glendale Public Service } \\
\text { Department }\end{array}$ & & & & $\mathrm{X}$ \\
\hline Gridley Municipal Utility & & & & $\mathrm{x}$ \\
\hline $\begin{array}{l}\text { Healdsburg, City of, } \\
\text { Municipal Electric }\end{array}$ & & & & $\mathrm{X}$ \\
\hline $\begin{array}{l}\text { Imperial Irrigation } \\
\text { District }\end{array}$ & & $\mathrm{X}$ & & \\
\hline $\begin{array}{l}\text { Lodi Municipal Electric } \\
\text { Works }\end{array}$ & & & & $\mathrm{x}$ \\
\hline $\begin{array}{l}\text { Iompoc I.ight and Water } \\
\text { Department }\end{array}$ & & & & $\mathrm{X}$ \\
\hline $\begin{array}{l}\text { Long Beach, City of, } \\
\text { Gas Department }\end{array}$ & & $\mathrm{X}$ & & \\
\hline $\begin{array}{c}\text { Los Angeles Department } \\
\text { of Water and Power }\end{array}$ & & & $\mathrm{X}$ & \\
\hline $\begin{array}{l}\text { Modesto Irrigation } \\
\text { Dictrict }\end{array}$ & & & $\mathrm{X}$ & \\
\hline $\begin{array}{l}\text { Pacific Gas and Electric } \\
\text { Company }\end{array}$ & $\mathrm{x}$ & & & \\
\hline $\begin{array}{l}\text { Pacific Power and Light } \\
\text { Company }\end{array}$ & $\mathrm{X}$ & & & \\
\hline Palo Alto, City of & & & $\mathrm{x}$ & \\
\hline
\end{tabular}


PROGRAM COVERAGE (continued)

\begin{tabular}{|c|c|c|c|c|}
\hline \multirow{2}{*}{ Utilities ${ }^{a}$} & \multirow{2}{*}{$\begin{array}{l}\text { Covered } \\
\text { regulated }\end{array}$} & \multicolumn{2}{|c|}{$\begin{array}{l}\text { Covered } \\
\text { nonregulated }\end{array}$} & \multirow{2}{*}{$\begin{array}{l}\text { Noncovered } \\
\text { voluntaryd }\end{array}$} \\
\hline & & State & Independent & \\
\hline $\begin{array}{l}\text { Pasadena Municipal Light } \\
\text { and Power Department }\end{array}$ & & $\mathrm{X}$ & $\cdot$ & - \\
\hline Redding Electric Utility & & & . & $\mathrm{X}$ \\
\hline $\begin{array}{l}\text { Riverside Public } \\
\text { Utilities }\end{array}$ & & & $\mathrm{X}$ & \\
\hline $\begin{array}{l}\text { Roseville Electric } \\
\text { Department }\end{array}$ & & & & $\mathrm{X}$ \\
\hline $\begin{array}{l}\text { Sacramento Municipal } \\
\text { Utility District }\end{array}$ & & & $\mathrm{x}$ & \\
\hline $\begin{array}{l}\text { San Diego Gas and } \\
\text { Electric Company }\end{array}$ & $\mathrm{X}$ & & & \\
\hline $\begin{array}{l}\text { Santa Clara Municipal } \\
\text { Electric Company }\end{array}$ & & & $\mathrm{X}$ & \\
\hline $\begin{array}{l}\text { Sierra Pacific Power } \\
\text { Company }\end{array}$ & $\mathrm{X}$ & & & \\
\hline $\begin{array}{l}\text { Southern California } \\
\text { Edison Company }\end{array}$ & $\mathrm{X}$ & & & \\
\hline $\begin{array}{l}\text { Southern California } \\
\text { Gas Company }\end{array}$ & $\mathrm{X}$ & & 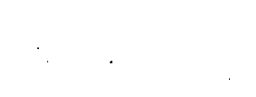 & \\
\hline $\begin{array}{l}\text { Truckee-Donner Public } \\
\text { Utility District }\end{array}$ & $\cdot$ & & & $\mathrm{X}$ \\
\hline $\begin{array}{l}\text { Uriah Electric } \\
\text { Department }\end{array}$ & & & $\cdot$ & $\mathrm{X}$ \\
\hline $\begin{array}{l}\text { Vernon Municipal Light } \\
\text { Department }\end{array}$ & & $\mathrm{x}$ & & \\
\hline CONNECTICUT & & & & \\
\hline Bozrah Light and Power & & & & $\mathrm{x}$ \\
\hline $\begin{array}{l}\text { Connecticut Light and } \\
\text { Power Company }\end{array}$ & $\mathrm{X}$ & & . & . \\
\hline $\begin{array}{c}\text { Connecticut Natural } \\
\text { Gas Corporation }\end{array}$ & $\mathrm{X}$ & & & \\
\hline $\begin{array}{l}\text { Groton, City of, Depart- } \\
\text { ment of Utilities }\end{array}$ & & & & $\mathrm{X}$ \\
\hline
\end{tabular}


PROGRAM COVERAGE (continued)

\begin{tabular}{|c|c|c|c|c|}
\hline \multirow[b]{2}{*}{ Utilities $^{\alpha}$} & \multirow{2}{*}{$\begin{array}{l}\text { Covered } \\
\text { regulated } b\end{array}$} & \multicolumn{2}{|c|}{$\begin{array}{l}\text { Covered } \\
\text { nonregulated }\end{array}$} & \multirow{2}{*}{$\begin{array}{l}\text { Noncovered } \\
\text { voluntary } d\end{array}$} \\
\hline & & State & Independent & \\
\hline $\begin{array}{l}\text { Hartford Electric Light } \\
\text { Company }\end{array}$ & $\mathrm{x}$ & & r & \\
\hline $\begin{array}{l}\text { Southern Connecticut Gas } \\
\text { Company }\end{array}$ & $\mathrm{x}$ & & & \\
\hline $\begin{array}{l}\text { United Illuminating } \\
\text { Company }\end{array}$ & $\mathrm{x}$ & & & \\
\hline $\begin{array}{l}\text { DELAWARE } \\
\text { Delaware Power and } \\
\text { Light Company }\end{array}$ & $\mathrm{x}$ & & & \\
\hline \multicolumn{5}{|l|}{ TOWA } \\
\hline Interstate Power Company & $\mathrm{x}$ & & & . \\
\hline $\begin{array}{l}\text { Iowa Electric Light and } \\
\text { Power Company }\end{array}$ & $\mathrm{x}$ & & $\cdot$ & \\
\hline $\begin{array}{l}\text { Iowa-I1linois Gas and } \\
\text { Electric Company }\end{array}$ & $\mathrm{X}$ & & & \\
\hline $\begin{array}{l}\text { Iowa Power and Light } \\
\text { Company }\end{array}$ & $\mathrm{x}$ & & & \\
\hline $\begin{array}{l}\text { Iowa Public Service } \\
\text { Company. }\end{array}$ & $\mathrm{x}$ & & & \\
\hline $\begin{array}{l}\text { Iowa Southern Utilities } \\
\text { Company }\end{array}$ & $\mathrm{x}$ & & & \\
\hline Minnesota Gas Company & $\mathrm{x}$ & & & \\
\hline $\begin{array}{l}\text { North Central Public } \\
\text { Service Company }\end{array}$ & $x$ & & & \\
\hline $\begin{array}{c}\text { Peoples Natural Gas } \\
\text { Division of Northern } \\
\text { Natural Cas Company }\end{array}$ & $\mathrm{x}$ & & & \\
\hline Union Electric Company & $\mathrm{X}$ & & & \\
\hline \multicolumn{5}{|l|}{ MICHIGAN } \\
\hline Consumers Fower Lompany & $\mathrm{x}$ & & & \\
\hline Detroit Edison Company & $\mathrm{X}$ & & & \\
\hline $\begin{array}{l}\text { Indiana and Michigan } \\
\text { Electri.c Company }\end{array}$ & $\mathrm{x}$ & & & \\
\hline
\end{tabular}




\section{PROGRAM COVERAGE (continued)}

\begin{tabular}{|c|c|c|c|c|}
\hline \multirow{2}{*}{$\therefore$ Utilities $^{a}$} & \multirow{2}{*}{$\begin{array}{l}\text { Covered } \\
\text { regulated } b\end{array}$} & \multicolumn{2}{|c|}{$\begin{array}{l}\text { Covered } \\
\text { nonregulated }\end{array}$} & \multirow{2}{*}{$\begin{array}{l}\text { Noncovered } \\
\text { voluntary } d\end{array}$} \\
\hline & & State & Independe & \\
\hline $\begin{array}{l}\text { Lansing Board of Water } \\
\text { and Light }\end{array}$ & & $\mathrm{x}$ & & 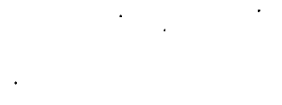 \\
\hline $\begin{array}{l}\text { Michigan Consolidated Gas } \\
\text { Company }\end{array}$ & $\mathrm{x}$ & & & . \\
\hline $\begin{array}{l}\text { Michigan Gas Utilities } \\
\text { Company }\end{array}$ & $\mathrm{X}$ & & & . \\
\hline Michigan Power Company & $\mathrm{x}$ & & & \\
\hline $\begin{array}{l}\text { Panhandle Eastern Pipe- } \\
\text { line Company }\end{array}$ & $\mathrm{X}$ & & $\cdot$ & r \\
\hline $\begin{array}{l}\text { Peoples Natural Gas } \\
\text { Division of Northern } \\
\text { Natural Gas Company }\end{array}$ & $\mathrm{X}$ & & & $\therefore$ \\
\hline $\begin{array}{l}\text { Southeastern Michigan } \\
\text { Gas Company }\end{array}$ & $\mathrm{x}$ & & & . \\
\hline $\begin{array}{l}\text { Wisconsin Electric } \\
\text { Power Company }\end{array}$ & $\mathrm{X}$ & & . & \\
\hline $\begin{array}{l}\text { Wisconsin Public } \\
\text { Service Corporation }\end{array}$ & $\mathrm{x}$ & & & \\
\hline NEW JERSEY & & & & \\
\hline $\begin{array}{l}\text { At lantic City Electric } \\
\text { Company }\end{array}$ & $\mathrm{x}$ & & & \\
\hline $\begin{array}{l}\text { Elizabethtown Gas } \\
\text { Company }\end{array}$ & $\mathrm{x}$ & & & \\
\hline $\begin{array}{l}\text { Jersey Central Power } \\
\text { and Light Company }\end{array}$ & $\mathrm{x}$ & & & \\
\hline $\begin{array}{l}\text { New Jersey Natural } \\
\text { Gas Company }\end{array}$ & $\mathrm{x}$ & & & \\
\hline $\begin{array}{l}\text { Public Service Electric } \\
\text { and Gas Company }\end{array}$ & $\mathrm{X}$ & & & \\
\hline $\begin{array}{l}\text { Rockland Electric } \\
\text { Company }\end{array}$ & $\mathrm{X}$ & & & \\
\hline $\begin{array}{l}\text { South Jersey Gas } \\
\text { Company }\end{array}$ & $\mathrm{X}$ & & & \\
\hline
\end{tabular}


PROGRAM COVERAGE (continued)

\begin{tabular}{|c|c|c|c|c|}
\hline \multirow[b]{2}{*}{ Utilities $^{a}$} & \multirow{2}{*}{$\begin{array}{l}\text { Covered } \\
\text { regulated }\end{array}$} & \multicolumn{2}{|c|}{$\begin{array}{l}\text { Covered } \\
\text { nonregulated }\end{array}$} & \multirow{2}{*}{$\begin{array}{l}\text { Noncovered } \\
\text { voluntary } d\end{array}$} \\
\hline & & State & Independent & \\
\hline \multicolumn{5}{|l|}{ NEW YORK } \\
\hline $\begin{array}{l}\text { Brooklyn Union Gas } \\
\text { Company }\end{array}$ & $\mathrm{X}$ & & & \\
\hline $\begin{array}{l}\text { Central Hudson Gas } \\
\text { and Electric } \\
\text { Corporation }\end{array}$ & $\mathrm{X}$ & & & \\
\hline $\begin{array}{l}\text { Columbia Gas of New } \\
\text { York, Inc. }\end{array}$ & $\mathrm{X}$ & & & \\
\hline $\begin{array}{l}\text { Consolidated Edison } \\
\text { Company of New York }\end{array}$ & $\mathrm{X}$ & & & \\
\hline $\begin{array}{l}\text { Tong Island Lighting } \\
\text { Company }\end{array}$ & $\mathrm{X}$ & & · & \\
\hline $\begin{array}{l}\text { National Fuei Gas Distri- } \\
\text { bution Corporation }\end{array}$ & $\mathrm{x}$ & & & \\
\hline $\begin{array}{c}\text { New York State Electric } \\
\text { and Gas Corporation }\end{array}$ & $\mathrm{X}$ & & & \\
\hline $\begin{array}{l}\text { Niagara Mohawk Power } \\
\text { Corporation }\end{array}$ & $\mathrm{X}$ & & & \\
\hline $\begin{array}{l}\text { Orange and Rockland } \\
\text { Utilities }\end{array}$ & $x$ & & & \\
\hline $\begin{array}{l}\text { Rochester Gas and } \\
\text { Electric Corporation }\end{array}$ & $\mathrm{X}$ & . & & \\
\hline \multicolumn{5}{|l|}{ OREGON } \\
\hline CP National Corporation & $\mathrm{X}$ & & & \\
\hline $\begin{array}{l}\text { Cascade Natural Gas } \\
\text { Corporation }\end{array}$ & $\mathrm{x}$ & & & \\
\hline $\begin{array}{l}\text { Central Lincoln Peoples } \\
\text { Utiltiy District }\end{array}$ & & & $x$ & \\
\hline $\begin{array}{l}\text { Eugene Water and } \\
\text { Electric Board }\end{array}$ & & & $\mathrm{X}$ & \\
\hline Idaho Power Company & $\mathrm{X}$ & & & \\
\hline $\begin{array}{l}\text { Northwest Natural Gas } \\
\text { Company }\end{array}$ & $\mathrm{X}$ & & & \\
\hline
\end{tabular}


PROGRAM COVERAGE (continued)

\begin{tabular}{|c|c|c|c|c|}
\hline \multirow[b]{2}{*}{ Utilities $^{\alpha}$} & \multirow{2}{*}{$\begin{array}{l}\text { Covered } \\
\text { regulated }\end{array}$} & \multicolumn{2}{|c|}{$\begin{array}{l}\text { Covered } \\
\text { nonregulated }\end{array}$} & \multirow{2}{*}{$\begin{array}{l}\text { Noncovered } \\
\text { voluntary }\end{array}$} \\
\hline & & State & Independent & \\
\hline $\begin{array}{l}\text { Pacific Power and Light } \\
\text { Company }\end{array}$ & $\mathrm{X}$ & & & ' \\
\hline $\begin{array}{l}\text { Portland General Electric } \\
\text { Company }\end{array}$ & $\mathrm{x}$ & & & \\
\hline \multicolumn{5}{|l|}{ RHODE ISLAND } \\
\hline $\begin{array}{l}\text { Blackstone Valley } \\
\text { Electric Company }\end{array}$ & $\mathrm{x}$ & & & \\
\hline $\begin{array}{l}\text { Block Island Power } \\
\text { Company }\end{array}$ & & & & $\mathrm{x}$ \\
\hline Bush and Warren Gas & & & & $\mathrm{X}$ \\
\hline $\begin{array}{l}\text { Narragansett Electric } \\
\text { Company }\end{array}$ & $\mathrm{X}$ & & 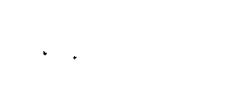 & \\
\hline Newport Electric Company & & & & $\mathrm{x}$ \\
\hline Pascoag Fire District & & & & $\mathrm{x}$ \\
\hline Providence Gas Company & $\mathrm{X}$ & & & \\
\hline South County Gas Company & & & & $\mathrm{x}$ \\
\hline Tiverton Gas Company & & & & $\mathrm{X}$ \\
\hline Valley Gas Company & & & & $\mathrm{x}$ \\
\hline SOUTH CAROLINA & & & . $\cdot$ & \\
\hline $\begin{array}{l}\text { Carolina Power and Light } \\
\text { Company }\end{array}$ & $x$ & & & \\
\hline Duke Power Company & $\mathrm{x}$ & & & \\
\hline $\begin{array}{l}\text { Piedmont Natural Gas } \\
\text { Company }\end{array}$ & $\mathrm{x}$ & & & \\
\hline $\begin{array}{l}\text { South Carolina Electric } \\
\text { and Gas Company }\end{array}$ & $\mathrm{X}$ & & & \\
\hline $\begin{array}{l}\text { South Carolina Public } \\
\text { Service Authority } \\
\text { (Santee Cooper) }\end{array}$ & & & $\mathrm{X}$ & \\
\hline $\begin{array}{l}\text { United Cities Gas } \\
\text { Company }\end{array}$ & $\mathrm{X}$ & & & \\
\hline
\end{tabular}


PROGRAM COVERAGE (continued)

\begin{tabular}{|c|c|c|c|c|}
\hline \multirow[b]{2}{*}{ Utilities ${ }^{a}$} & \multirow{2}{*}{$\begin{array}{l}\text { Covered } \\
\text { regulated } b\end{array}$} & \multicolumn{2}{|c|}{$\begin{array}{c}\text { Covered } \\
\text { nonregulated }\end{array}$} & \multirow{2}{*}{$\begin{array}{l}\text { Noncovered } \\
\text { voluntary }\end{array}$} \\
\hline & & State & $\overline{\text { Independent }}$ & \\
\hline
\end{tabular}

TEXAS

Arkansas-Louisiana Gas Company

$\mathrm{X}$

Austin Electric Department

$\mathrm{X}$

Central Power and Light Company

$\mathrm{X}$

Dallas Power and Light Company

$\mathrm{X}$

El Paso Electric Company $X$

Entex, Inc.

$\mathrm{x}$

Garland Electric Department

$\mathrm{X}$

Gulf States Utility

Company

X

Ilouston Lighting and Power Company

$\mathrm{X}$

Lone Star Gas Company X

Pedernales Electric Cooperative, Inc.

$\mathrm{X}$

Peoples Natural Gas Division of Northern Natural Gas Company

$\mathrm{X}$

Pioneer Natural. Gas Company

$\mathrm{X}$

San Antonio Public Service Board

$\mathrm{X}$

Southern Union Gas Company

$\mathrm{X}$

Southwestern Electric Power Company $\mathrm{X}$

Southwestern Electric Service Company

$\mathrm{X}$

Southwestern Public Company 
PROGRAM COVERAGE (continued)

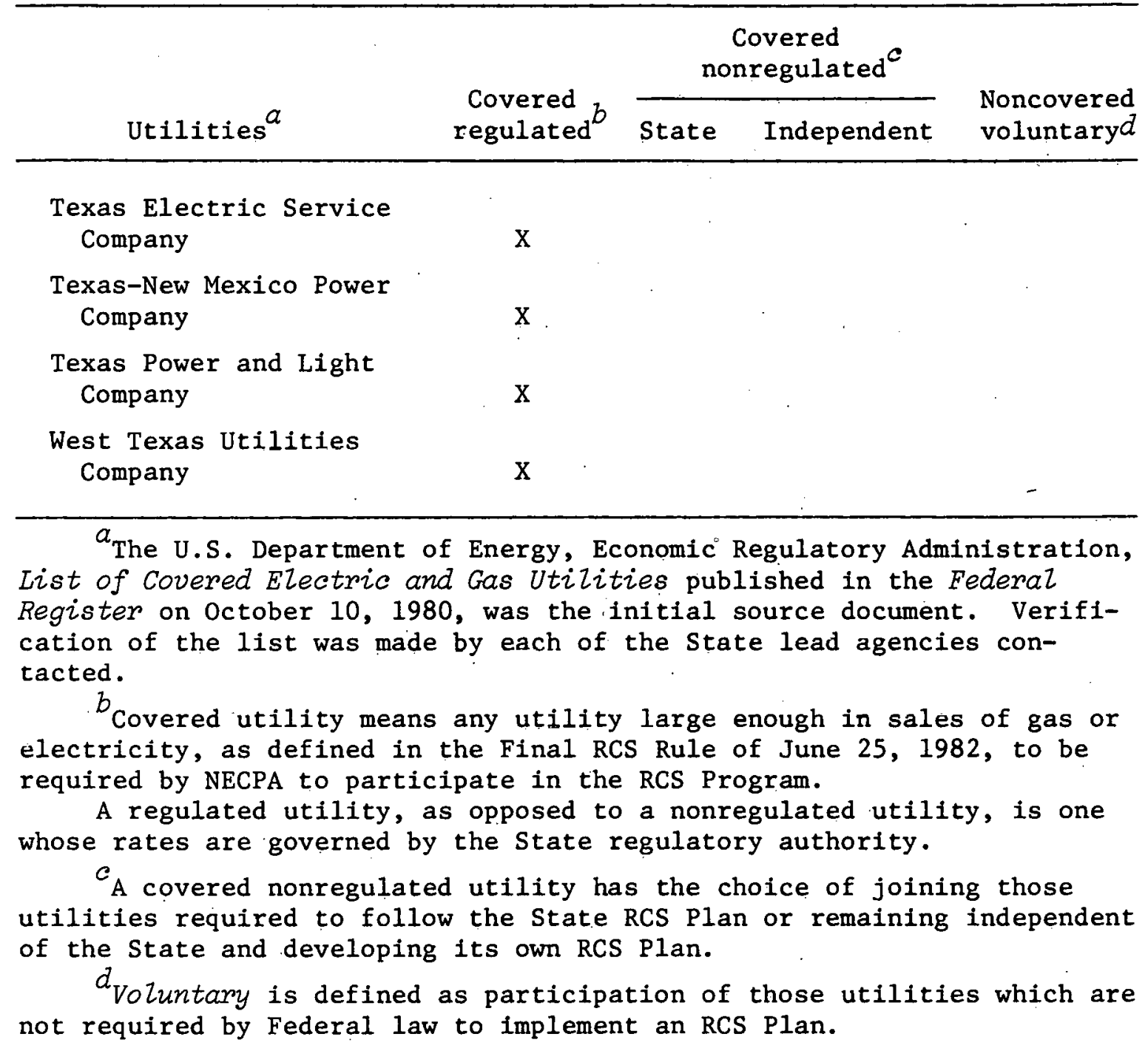


THIS PAGE

WAS INTENTIONALLY

LEFT BLANK 
INTERNAL DISTRIBUTION

$\begin{aligned} & \text { 1. } \text { S. I. Auerbach } \\ & \text { 2. } \text { L. G. Berry } \\ & \text { 3. M. A. Broders } \\ & \text { 4-8. A. R. Ehrenshaft } \\ & \text { 9-13. L. M. Frogge } \\ & \text { 14. W. Fulkerson } \\ & \text { 15. H. B. Gerstner } \\ & \text { 16. M. P. Guthrie } \\ & \text { 17. E. A. Hirst } \\ & \text { 18. M. A. Karnitz } \\ & \text { 19. A. S. Loeb1 } \\ & \text { 20. L. Menendez } \\ & \text { 21. W. R. Mixon }\end{aligned}$

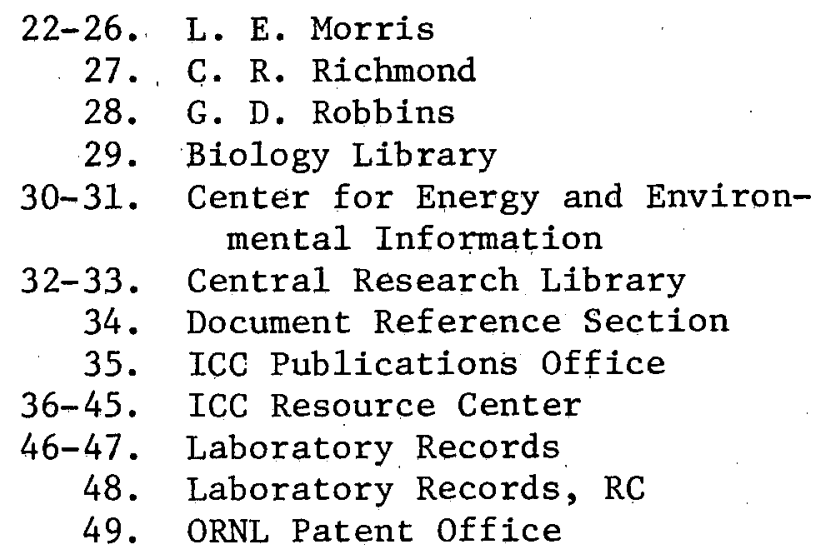

50. Executive Director, Oak Ridge Associated Universities, P.0. Box 117, Oak Ridge, Tennessee 37830.

51. Office of Assistant Manager, Energy Research and Development, U.S. Department of Energy, Oak Ridge Operations Office, Oak Ridge, Tennessee 378.30 .

52-78. Technical Information Center, U.S. Department of Energy, Oak Ridge, Tennessee 37830 . 